\title{
The Trouble With Shadow Government
}

Howard M. Wasserman

Florida International University College of Law, howard.wasserman@fiu.edu

Follow this and additional works at: https://ecollections.law.fiu.edu/faculty_publications

Part of the Law and Politics Commons, Law and Society Commons, National Security Law Commons, Other Law Commons, and the State and Local Government Law Commons

\section{Recommended Citation}

Howard M. Wasserman, The Trouble With Shadow Government, 52 Emory L.J. 281 (2003).

Available at: https://ecollections.law.fiu.edu/faculty_publications/73

This Article is brought to you for free and open access by the Faculty Scholarship at eCollections. It has been accepted for inclusion in Faculty Publications by an authorized administrator of eCollections. For more information, please contact lisdavis@fiu.edu. 


\section{HEINONLINE}

Citation: 52 Emory L.J. 2812003

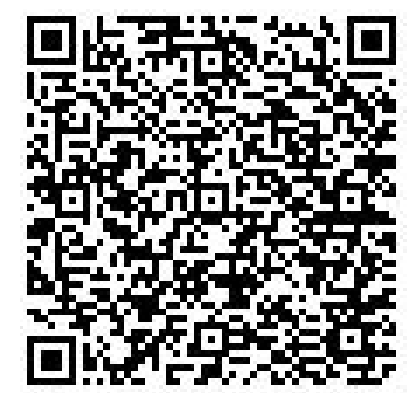

Content downloaded/printed from

HeinOnline (http://heinonline.org)

Tue Nov 11 18:05:26 2014

-- Your use of this HeinOnline PDF indicates your acceptance of HeinOnline's Terms and Conditions of the license agreement available at http://heinonline.org/HOL/License

-- The search text of this PDF is generated from uncorrected OCR text.

-- To obtain permission to use this article beyond the scope of your HeinOnline license, please use:

https://www.copyright.com/ccc/basicSearch.do?

\&operation $=$ go\&search $\mathrm{Type}=0$

\&lastSearch $=$ simple\&all=on\&titleOrStdNo=0094-4076 


\title{
THE TROUBLE WITH SHADOW GOVERNMENT
}

\author{
Howard M. Wasserman*
}

Presidential succession and government continuity suddenly is a hot topic. The September 11 terrorist attacks and the subsequent War Against Terrorism have brought to the fore the possibility of a catastrophic terrorist attack, perhaps involving small concealed nuclear devices, laying waste to all of Washington, D.C., killing the president and vice president, and destroying Congress and the federal government. This prospect in turn raises procedural questions about how to preserve the federal government, particularly the executive branch, and how to maintain governance in the federal system. The central concerns must be who will succeed to the presidency and assume the executive power under the Constitution and how to repopulate the political branches and departments in the federal government.

It initially was feared that intended targets of the coordinated September 11 attacks included Congress, President Bush traveling aboard Air Force One, and Vice President Cheney at the White House. None of these aspects of the attacks succeeded, but they raise the specter of a successful terrorist attack creating a double vacancy in the presidency and vice presidency, and triggering the presidential succession statute.' Much of the activity on the morning of September 11 was geared to ensuring the immediate safety of the President, Vice President, and members of the cabinet in a secure location, with the intent of maintaining some executive branch officer at the head of the federal government. ${ }^{2}$

\footnotetext{
* Assistant Professor, Florida International University College of Law. J.D. (1997); B.S. (1990), Northwestem University. Thanks to Jim Chen, Steven Gey, John Harrison, and B.J. Priester for their thoughts, comments, and suggestions. This Article was presented to the faculties at Cleveland-Marshall College of Law and Florida International University College of Law.

1 See U.S. CONST. art. II, \& 1, cl, 6 ("Congress may by Law provide for the Case of Removal, Death, Resignation or Inability, both of the President and Vice President, declaring what Officer shall then act as President . . ."); 3 U.S.C. § 19 (2000); William F. Brown \& Americo R. Cinquegrana, The Realities of Presidential Succession: "The Emperor Has No Clones," 75 GEo. L.J. 1389, 1431-35 (1987); Howard M. Wasserman, Structural Principles and Presidential Succession, 90 KY. L.J. 345, 354-56 (2002).

2 See Meet the Press (NBC television broadcast, Sept. 16, 2001) (interviewing Vice President Richard Cheney).
} 
On one hand, concerns about an even more catastrophic, nuclear-based terrorist attack destroying the federal government appear overstated. It is not clear that a terrorist attack is any more likely to succeed in taking out the top tier of the federal government and leaving it headless than a Soviet nuclear strike during the Cold War. Indeed, it arguably would have been easier to destroy the entire federal structure (and the entire nation) through one grandscale nuclear First Strike than through a series of finely coordinated simultaneous individual attacks or with several briefcases containing small nuclear devices. This perhaps means that the extant statutory succession procedures, which have been in place since 1947 and which functioned reasonably well throughout the Cold $\mathrm{War}^{3}{ }^{3}$ remain sufficient. For example, common practice has been for one cabinet officer to remain outside Washington when the president addresses a Joint Session of Congress attended by members of the cabinet; this practice guarantees that, in the event of an attack directed at Congress when most members of the legislative and executive branches are present, one officer would remain to assume control of the executive branch. ${ }^{4}$

On the other hand, terrorist suicide bombers wielding nuclear devices benefit from some element of surprise. There would be no advance warning of such an attack, as there would have been with a Soviet missile launch, meaning less (or no) opportunity to move the president and those in the line of succession to safety. The surprise perhaps makes this attack better able to decapitate the federal government. Thus, while we must consider some ghoulish and morbid scenarios straight out of Independence Day ${ }^{5}$ or Mars Attacks, ${ }^{6}$ the issue of how to maintain or replace federal officials and how properly to continue operations of the federal government has become a genuine topic of concern.

3 The most vivid double vacancy moment in that time came in March 1981, following the assassination attempt on President Ronald Reagan, when Secretary of State Alexander Haig announced at a White House press briefing that he was "in control, here in the White House," despite the fact that the Vice President, Speaker of the House, and President Pro Tempore of the Senate-all ahead of Haig in the line of successionwere alive and able to assume the presidency. See Richard V. Allen, The Day Reagan Was Shot, AtLAnTIC MONTHLY, Apr. 2001, at 64, 66; Wasserman, supra note 1, at 345.

4 When President Bush addressed a joint session of Congress two months after September 11, the officer absent from the address was Vice President Cheney.

5 INDEPENDENCE DAY (20th Century Fox 1996) (depicting an alien spaceship hovering over the White House and blowing it apart with a laser weapon).

6 MARS ATTACKS! (Warner Bros. 1996) (depicting Martian leader addressing a joint session of Congress on national television and killing off the entire gallery with a laser, then killing the President during a meeting in a bunker). At the end of the film, after the Martians have been defeated, the President's teenage daughter becomes the leader of the country. Id. 
The succession policy focuses have been manifold. First, there have been proposals to amend the double vacancy succession statute by changing the order of succession and by extending the succession order to include all of Congress, sub-cabinet-level executive officers, and, most significantly, state governors. Second, there has been a focus on ensuring the continuation of the federal government and its operations. The most notorious of these proposals is the Bush Administration's "shadow government," details of which are not widely known and have not been shared either with the public or with Congress. The plans appear to involve officers from every executive department and agency, secured in an unknown location, prepared to emerge and assume control following an attack, perhaps with Vice President Cheney at the helm. "Continuity in government" has come to be the most important step in response to an attack.' The President's plans, apparently limited only to the executive branch, have led to calls for similar continuity plans for the other branches. $^{8}$ However, the focus on continuity ignores concerns about the

7 See President George W. Bush, Remarks Following a Roundtable Discussion on Retirement Savings and an Exchange with Reporters in Des Moines, lowa, in 38 WEEKLY COMP. PRES. DoC. 316, 317 (Mar. 1, 2002), available at http://frwebgate.access.gpo.gov/cgi-bin/getdoc.cgi?dbname=2002_presidential_documents \&idocid=pd04mr02_txt-23.pdf (comments of President George W. Bush) ("I have an obligation as the President ... to the American people to . . . put measures in place that should somebody be successful in attacking Washington, D.C., there's an ongoing government.").

8 See Thomas S. Foley \& Newt Gingrich, If Congress Were Attacked, WASH. POST, Mar. 17, 2002, at B9 (proposing continuity plan for House of Representatives and Senate); see also Hearing on FY03 Budget for the Supreme Court Before the S. Subcomm. on Commerce, Justice, State, and the Judiciary, 107th Cong. (2002), available at http://web.lexis-nexis.com/congcomp/document?_m=e40074de01b6ca51 labf0951 eb66a04f (statements of Leonidas Ralph Mecham, Director of Administrative Office of U.S. Courts, and the Honorable John G. Heyburn II, Chairman, Conference on the Budget of the Judicial Conference of the United States) (describing continuity-of-operations planning for federal judiciary).

We do not consider continuity or repopulation of the judicial branch. Assuming the terrorist attacks are targeted at Washington, D.C., the Supreme Court likely would be the primary court disabled. However, district and appellate courts throughout the nation should continue to function, hearing and deciding cases. Moreover, to the extent the federal courts need to be actors in any constitutional disputes arising in the early months after the attack, those disputes must begin in the lower courts and work their way through the system, and would not get to the Supreme Court for at least a few months, except in the extreme and unusual case. See Bush v. Gore, 531 U.S. 98, 100 (2001) (tracing chronology in presidential election dispute in which Florida Supreme Court decided case on December 8, United States Supreme Court granted a stay and certiorari on December 9, and reversed the state court on December 12); Cass Sunstein, Of Law and Politics, in THE VOTE: Bush, GORE, AND THE SUPREME COURT 1, 2-4 (Cass R. Sunstein \& Richard A. Epstein eds., 2001) (tracing one-month chronology of election and dispute). Repopulation of the Supreme Court, as well as any other federal courts whose members might be killed in an attack, can await repopulation of the political branches of the federal government, see infra notes 137-72 and accompanying text, then can proceed via ordinary procedures of presidential appointment and Senate confirmation.

In the fall of 2002, the American Enterprise Institute and the Brookings Institution jointly established the Continuity of Government Commission to study and recommend constitutional and statutory reforms to 
legitimacy of any acting federal government. It also obscures the more important question of repopulating the federal government, of the manner and timing of choosing new members of Congress, a new president and vice president, and a new cabinet.

The focus here is on the underlying legal and constitutional assumptions of these mass-destruction scenarios, the legal and constitutional problems with proposed solutions, and the creation of continuity and repopulation procedures that would be constitutionally valid and legitimate. The public as a whole is likely unconcerned with such legal niceties as the constitutional validity of what remains of the executive branch after an attack. ${ }^{9}$ Nevertheless, in anticipating even the most tragic and unsettling events, we should ensure that any continuity processes conform to constitutional requirements as well as to underlying structural principles, such as separation of powers, federalism, and democracy. ${ }^{10}$ And we should make the necessary constitutional or statutory changes to ensure that the present legal landscape can accommodate a continuity mechanism in the event of a mass destruction.

\section{QUESTIONS OF PRESIDENTIAL SUCCESSION}

\section{A. Proposed Changes to the Succession Statute}

Presidential succession is a mix of constitutional and statutory procedures. The Constitution provides that, in the event of a vacancy in the presidency, the vice president becomes president." The Constitution then grants to Congress the power to provide by law for simultaneous vacancies in both offices by designating the "Officer" who is to "act as president" until the president is able

handle the mass-destruction scenario in all three branches of the federal government. As this Article went to press, the Commission was about to release its first report and recommendation on congressional continuity.

9 Cf. Gary Lawson \& Guy Seidman, When Did the Constitution Become Law?, 77 NOTRE DAME L. REV. 1,25 (2001) (arguing that the public in 1788 was not concerned with legal niceties of whether the Constitution, having been ratified, was in fact controlling law, but rather with the concrete problems of putting together a functioning union).

10 See Wasserman, supra note 1, at 348-51 (discussing the role of structural principles-separation of powers, democracy, and political partisanship-and how the succession statute conforms to those principles); see also Akhil Reed Amar \& Vikram David Amar, Is the Presidential Succession Law Constitutional? 48 STAN. L. REV. 113, 139 (1995) (calling for changes to the succession statute because it might make someone president who is neither legitimate nor constitutional).

11 See U.S. ConST. amend. XXV, \&1 ("In case of the removal of the President from office or of his death or resignation, the Vice President shall become President."). 
to resume office or a new president is elected. ${ }^{12}$ The designation of an officer to "act as president" (as opposed to "becom[ing] President") ${ }^{13}$ derives from the Framers' refusal to grant the legislature the constitutional power to appoint the executive; Congress may choose someone to act as executive, to occupy the White House temporarily, but Congress may not appoint a president. ${ }^{14}$ The distinction largely is semantic, as it appears that the acting president assumes the whole of the constitutional executive power and may exercise the same Article 11 powers as a president. ${ }^{15}$

The current succession statute, codified at 3 U.S.C. $\$ 19$, was passed in 1947; it provides for succession by the Speaker of the House of Representatives, followed by the President Pro Tempore of the Senate, followed by cabinet officers, beginning with the Secretary of State and proceeding according to the age of the department. ${ }^{16}$ The statute does not provide for any officer or individual beyond the cabinet, likely on the 1940s assumption that the death of every cabinet officer was unlikely and that at least one enumerated officer always would survive to become acting president.

Several commentators have argued that as a matter of constitutional text and/or structural principle, legislative officers should not be in the line of

12 See U.S. CONST. art. II, § 1, cl. 6 ("Congress may by Law provide for the Case of Removal, Death, Resignation, or Inability, both of the President and Vice President, declaring what Officer shall then act as President, and such Officer shall act accordingly, until the Disability be removed, or a President shall be elected.").

13 See Steven G. Calabresi, The Political Question of Presidential Succession, 48 STAN. L. REV. 155, 162-63 n.40 (1995) (arguing that, under the Twenty-fifth Amendment, only the vice president actually becomes President, but all other successors become acting president).

14 See Tadahisa Kuroda, The Origins of the TwelfTh Amendment 8 (1994); Brown \& Cinquegrana, supra note 1, at 1436; Wasserman, supra note 1, at 353; see also id. at 363 (discussing rejection of legislative appointment of executive under the Constitution in light of concerns that such executive would lack necessary independence)

15 But see Brown \& Cinquegrana, supra note 1, at 1442-43 (describing uncertainty as to whether an acting president could appoint a vice president under the Twenty-fifth Amendment and whether that newly appointed vice president would become a prior entitled officer who should immediately assume the executive power). Political fairness might suggest that an acting president ought not nominate federal judges, especially Supreme Court Justices, who will remain on the court for life. Instead, nominations should await the election of a new president. See infra notes 157-66 and accompanying text.

16 See 3 U.S.C. $\$ 19$ (a), (b), (d)(1) (2000) (providing for cabinet succession order of Secretary of State, Secretary of the Treasury, Secretary of Defense, Attorney General, Secretaries of the Interior, Agriculture, Commerce, Labor, Health and Human Services, Housing and Urban Development, Transportation, Energy, Education, and Veterans Affairs); see also Amar \& Amar, supra note 10, at 134-35; Brown \& Cinquegrana, supra note 1, at 1431-33; Wasserman, supra note 1, at 354 \& n.32. The new Secretary of Homeland Security, a position and department established in 2002, should be added to the end of the line. See Homeland Security Act of 2002, Pub. L. No. 107-296, 116 Stat. 2135 (codified as amended in scattered titles and sections of U.S.C.) (establishing Department of Homeland Security as an executive department). 
succession, that the executive power should devolve only to executive branch officers. ${ }^{17}$ The common recommendation is a statute that provides for cabinet succession only, beginning with the Secretary of State, with a special election to choose a new president and vice president according to ordinary constitutional procedures as soon as practicable. ${ }^{18}$

The only proposed change to $\S 19$ in the wake of September 11 was House Bill 3816, introduced in the 107th Congress in February 2002, but not acted upon. The bill made two primary adjustments to the statute. First, the bill removed the President Pro Tempore from the line of succession in favor of the Senate Majority or Minority Leader, depending on party control of the Senate and advance designation by the president. ${ }^{19}$ This change recognized that the President Pro Tempore does not wield primary responsibility for the direction and control over the legislative or partisan agenda. The President Pro Tempore is the senior-most member of the Senate majority party and the presiding officer for debate, but real control over Senate business rests with the party caucus leaders, particularly the Majority Leader. Second, it gave the president the power to designate in advance the legislative officer she wants as statutory successor, either the Speaker or the House Minority Leader and either the Senate Majority of Minority Leader, depending on whether the president's party is in the majority or minority in each house of Congress; the president could change that designation if party control changes in the House, in order to ensure that her successor always will be the congressional head of her political party. $^{20}$

The solution proposed in House Bill 3816 is troubling. The bill adhered to the misplaced belief that a member of Congress should be at the head of the line of double-vacancy succession, a belief that is inconsistent with a proper understanding of separation of powers and democracy. ${ }^{21}$ Allowing the president to designate the legislative head of her own party as successor does

17 See Amar \& Amar, supra note 10, at 136 (arguing that the most straightforward reading of the text and structural considerations demand the conclusion that the Speaker and President Pro Tempore are not "officers" within the meaning of the Succession Clause); Calabresi, supra note 13, at 156 (agreeing with that conclusion, but arguing that the matter is a political question, not subject to judicial review); Wasserman, supra note 1, at 409-10 (arguing that considerations of separation of powers, political partisanship, and democracy demand that executive power devolve to cabinet officers, not congressional officers).

18 See Amar \& Amar, supra note 10, at 137-38; Calabresi, supra note 13, at 156; Wasserman, supra note 1 , at 410 .

19 See H.R. 3816, 107th Cong. \& 2 (2002).

20 See id.

21 See Wasserman, supra note 1, at 365, 409; see also Amar \& Amar, supra note 10, at 118; Calabresi, supra note 13, at $163-64$. 
remedy one defect in the present statute: the risk of succession bringing about a change in party control (and policy direction) of the White House when a Speaker of one political party succeeds a president of another. ${ }^{22}$ However, even if party caucus leaders are legislative officers who are constitutionally eligible for presidential succession, ${ }^{23}$ they are legislative officers whose existence is not constitutionally mandated. The Constitution expressly commands that there be a Speaker of the House and a President Pro Tempore of the Senate; $;^{24}$ it does not require that there be formal party caucuses or leaders of those caucuses. ${ }^{25}$ Each house establishes those and other offices unilaterally through the power to establish its own rules of operation; ${ }^{26}$ each house also may eliminate them unilaterally. We should hesitate before placing in the statutory line of presidential succession, established through bicameralism and presentment, a legislative officer whose position is not guaranteed by the Constitution and may be eliminated by the singular act of a simple majority of one house.

\section{B. Extending the Line of Succession}

The bigger problem with House Bill 3816 is that it did nothing to improve the ability of $\S 19$ to address any of the new, supposedly unique concerns arising from a massive terrorist attack killing more than the president and vice president and inflicting far greater damage on the structure of the federal government. The bill continued to assume that one of the top legislative or cabinet officers will survive to become acting president; it merely tinkered with partisan elements of succession.

But the reason for having this conversation about "continuity in government" is the assumption that the new, post-September 11 risk of a larger and more comprehensive and destructive attack demands more comprehensive

22 See Wasserman, supra note 1, at 386-87. Cf. The West Wing (NBC television broadcast, May 14, 2003) (depicting fictional liberal Democrat President Josiah Bartlett, facing a personal crisis and serving without a vice president, declaring himself temporarily unable to discharge the power and duties of his office and transferring executive power to the conservative Republican Speaker of the House).

23 See infra notes $27-33$ and accompanying text.

24 See U.S. CONST. art. I, \$2, cl. 5 ("The House of Representatives shall chuse their Speaker and other Officers ...."); id. $\S 3$, cl. 5 ("The Senate shall chuse their other Officers, and also a President pro tempore, in the Absence of the Vice President....").

25 See Wasserman, supra note 1, at 370 ("The Constitution of 1787 makes no mention of political parties ..."); Steven G. Calabresi, Political Parties As Mediating Institutions, 61 U. CHI. L. REv. 1479, 1494 \& n.54 (1994) ("[T]he vast bulk of our Constitution was designed to discourage parties and not to accommodate them.").

26 See U.S. ConST. art. I, § 5, cl. 2. 
succession considerations. One answer might be a deeper line of succession, with more officials enumerated in the line, including remaining members of Congress, state governors, and sub-cabinet level executive officers. But such extensions of the statutory line demand a constitutional amendment in order to be implemented. Moreover, an extension of the line of succession would call into question the democratic legitimacy of any successor and would present intractable drafting problems for Congress.

\section{Rank-and-File Members of Congress}

The Constitution empowers Congress to designate the "Officer" who will act as president. ${ }^{27}$ The term "Officer" appears in several places in the Constitution, but the Succession Clause is the only provision in which the word appears without some modifier. ${ }^{28}$ At its narrowest meaning, the unmodified "Officer" could be shorthand for "Officers of the United States" or "Officers under the United States," synonymous terms which include executive branch officers only. ${ }^{29}$ The Speaker of the House and President Pro Tempore of the Senate perhaps are legislative officers, ${ }^{30}$ but they are not officers of or under the United States. It thus is at least textually arguable that they do not fall within the unmodified "Officers" in the Succession Clause." On this understanding, only executive branch officers are eligible to act as president but no member of Congress is eligible to do so.

27 See id. art. II, $\$ 1, \mathrm{cl} .6$.

28 Compare id. art. II, § 6, cl. 1 ("Officer"), with, id. art. 1, \& 6, cl. 2 ("No Senator or Representative shall, during the Time for which he was elected, be appointed to any civil Office under the Authority of the United States ... and no Person holding any Office under the United States, shall be a Member of either House during his Continuance in Office.") (emphasis added), id. art. II, $§ 2, \mathrm{cl} .2$ ("[A]nd he shall nominate, and by and with the Advice and Consent of the Senate, shall appoint ... all other Officers of the United States. ...") (emphasis added), and id. art. II § 4 ("The President, Vice President and all civil Officers of the United States, shall be removed from Office on Impeachment for, and Conviction of, Treason, Bribery, or other high Crimes and Misdemeanors.") (emphasis added). See also Amar \& Amar, supra note 10, at 114-17; Calabresi, supra note 13 , at $158-60$.

29 See Amar \& Amar, supra note 10, at 115-16 ("[F]ederal legislators are neither 'Officers under the United States,' nor (to the extent that there is any difference) 'Officers of the United States.'"); Calabresi, supra note 13, at 163 ("[I]t is more likely than not that the word 'Officer' means 'Officer of the United States." ).

30 See U.S. CONST, art. I, \& 2, cl. 5 ("The House of Representatives shall chuse their Speaker and other Officers ...."); $i d . \S 3, \mathrm{cl} .5$ ("The Senate shall chuse their other Officers, and also a President pro tempore, in the Absence of the Vice President, or when he shall exercise the Office of President of the United States."); see also John F. Manning, Not Proved: Some Lingering Questions About Legislative Succession to the Presidency, 48 STAN. L. Rev. 141, 143 (1995) (describing the Speaker and President Pro Tempore as officers of both houses of Congress).

31 See Amar \& Amar, supra note 10, at 137; Calabresi, supra note 13, at 159. 
The counterargument is that the unmodified term "Officers" is broader than "Officers of the United States" and also may include legislative officers, such as the Speaker and President Pro Tempore. ${ }^{32}$ Selection of some members of each house as legislative officers places them in a different class than other legislators and makes them constitutionally eligible for succession. But it does not necessarily follow that rank-and-file members of Congress similarly are eligible for succession. The Succession Clause might permit succession by the smaller group of legislative officers but not the larger group of ordinary legislators who have not taken the next step of being selected as legislative officers. $^{33}$ This extension to rank-and-file representatives would require a constitutional amendment.

Constitutionality aside, this extension would be impossible to draft. How would Congress determine a succession order among members of Congress? Legislation must be written in broad, general terms, in order to have full prospective effect and to apply not only to current circumstances and the current Congress, but to similar circumstances in future Congresses. An extended succession order must be established without reference to the current political landscape and current political interests, by referencing only particular Senate or House seats from particular states or districts without regard to who holds any seat at a given time and without regard to the seniority or political party affiliation of the present holder of that seat. ${ }^{34}$

An extended statute inevitably would have to order among particular states and districts. But how can Congress neutrally decide whether a representative from New York should be higher in the succession line than a representative from Alabama or from Colorado or from Illinois? Even within a given state, who from the New York delegation should be higher in the line, someone from a rural upstate district, from a suburban Long Island district, or from New York City? Who from California should be higher, a representative from San Francisco or from Orange County?

32 See Manning, supra note 30 , at 144 (arguing that the failure to use the phrase "Officers of the United States" suggests that the Succession Clause refers to a broader class of actors).

33 See id. at 143 (suggesting an understanding of the word "Officer" in the Succession Clause that would exclude ordinary legislators but include the officers of both houses of Congress).

34 See Calabresi, supra note 13, at $156 \mathrm{n} .8$ (arguing that a succession scheme must be unaffected by the political leanings of the current occupants of the offices that might be placed in the line of succession and calling for consideration of the matter "behind a veil of ignorance"); Elizabeth Garrett, Institutional Lessons from the 2000 Presidential Election, 29 FLA. ST. U. L. REV. 975, 986 (2001) (emphasizing the need for a detailed ex ante framework on selection issues to constrain discretion and channel partisanship). 
Geographic and regional conflicts made compromise at the Constitutional Convention difficult enough. ${ }^{35}$ Such conflicts remain, between the Northeast and Midwest, between the South and the Pacific Northwest, among rural, urban, and suburban areas. ${ }^{36}$ One need only look at the map from the 2000 presidential election to know that regional and geographic differences remain ever-present. The very act of proposing and establishing an order among members of Congress introduces favoritism and nonuniformity not subject to clear compromise; it creates the very inter-state or inter-region conflicts that the Framers sought to minimize. At best, a statute might provide for succession in general terms according to seniority of members, without specifying particular seats. But that still leaves the question of how to decide among numerous members having equal seniority, requiring the same difficult ordering among states and districts.

Finally, there would be structural problems with the national democratic legitimacy of a rank-and-file legislator acting as president. The notion that the Speaker of the House is a nationally democratic choice to act as president is based on the fact that the Speaker is (as a matter of practice) a member of the House, elected by the voters of her congressional district, and is placed in the Speakership by a majority of all the members of the House, themselves popularly elected. ${ }^{37}$ In other words, the Speaker, popularly elected by her own local constituency, receives an additional, broader popular imprimatur and democratic legitimacy via the other members of the House, who together reflect a national constituency. Whatever the merits of that view of the Speaker, ${ }^{38}$ that token of nationwide legitimacy is absent as to the ordinary House member who never received even indirect approval by any constituency beyond a majority of the voters in her congressional district.

35 See Amar \& Amar, supra note 10, at 117 n.25; Michael B. Schill, Intergovernmental Takings and Just Compensation: A Question of Federalism, 137 U. PA. L. REv. 829, 887 (1989) ("Conflict among regions has played a central role in the history of the nation. Fears of interstate rivalry and exploitation took on great importance at the Constitutional Convention of 1787 and the ensuing ratification process."); id. at $868 \mathrm{n} .146$ (describing concerns at Convention for large states, particularly from the South, dominating small states, particularly from the North).

36 See Schill, supra note 35 , at 887 (describing a rise in conflicts among states and regions in the late 1980s).

37 See Harry S. Truman, Special Message to the Congress on Succession to the Presidency, in PuB. PAPERS 128, 129 (June 19, 1945); see also Wasserman, supra note 1, at 356-57 (describing Truman's arguments in favor of an altered succession order).

38 See Wasserman, supra note 1 , at 403-05 (questioning the conclusion that the Speaker is a more democratic official, on the national level, than a cabinet officer who has been hand-picked by the nationally elected president to help carry out the executive power). 


\section{State Governors}

It similarly would be constitutionally impermissible, politically unfeasible, and nationally undemocratic to include state governors in the line of succession. The best reading of the word "Officer" in the Succession Clause, unmodified by reference to any level of government, means an officer of the government of the United States, of the federal government, an officer holding a position created by and drawing authority from the federal Constitution or federal law. ${ }^{39}$ A state governor is not an officer eligible for succession under this view. This reading is historically sound, given the Framers' intention to create a stronger, more national, and more independent central government. ${ }^{40}$ That purpose is undermined if federal executive power devolves to a person whose office and authority, the basis for her eligibility to act as president, are grounded entirely in state law and whose loyalties perhaps lie more with state than national interests.

The same problems of sectional favoritism and nonuniformity arise in placing governors in the line. ${ }^{41}$ How can Congress decide between the governors of New York and Virginia or California and Kansas or Mississippi and Ohio? Any choice again reflects regional and geographic biases, and any attempt to draw these lines again requires Congress to yield to the regional conflicts that the Constitution seeks to limit.

Finally, like a rank-and-file member of Congress, a state governor never has been presented to or subject to consideration by a nationwide electoral constituency, even indirectly. The governor lacks any possible nationwide democratic legitimacy in acting as president. Her public support base is limited to her state-wide constituency and no national body or electoral constituency accords any imprimatur to her service at the head of the federal executive branch.

\section{Sub-Cabinet Executive Branch Officers}

The third possible extension of the line of succession would include subcabinet-level executive officers, undersecretaries, and deputies. Such inferior officers are officers of or under the United States, unquestionably eligible

\footnotetext{
39 See Amar \& Amar, supra note 10, at 117; Calabresi, supra note 13, at 161; Manning, supra note 30, at

40 See Amar \& Amar, supra note 10, at 117

41 See id.
} 143. 
officers for Succession Clause purposes, even under the narrowest view of that term. Because they are members of the executive branch, there also is no separation of powers problem with their succession to the White House.

But democratic problems nevertheless remain with their elevation. The argument against primary cabinet succession was the perceived undemocratic quality of the president appointing her own contingent successor, as compared to succession by a popularly elected member of Congress. ${ }^{42}$ These concerns are alleviated by a proper understanding of the true democratic quality of cabinet officers, which derives from two sources. First, cabinet members draw apostolic democratic legitimacy by virtue of their selection by the nationally elected populist president to help carry out the executive power. ${ }^{43}$ Second, they gain national democratic legitimacy by virtue of their confirmation by a majority of the Senate, whose members are popularly elected. ${ }^{44}$

The latter democratic imprimatur is absent with respect to many deputies and under-secretaries, appointed exclusively and unilaterally by the president or, still more problematically, by a cabinet officer or department head herself not popularly elected by any constituency. ${ }^{45}$ Such inferior officers would be fairly low in the statutory order, succeeding only in the event of this feared destruction of the entire upper tier of the federal government. But their succession, even on an emergency, short-term, and unlikely basis, remains subject to democratic objection.

Including inferior officers in the line of succession also creates drafting problems. There is no obvious way to order the myriad inferior officers across executive departments and agencies. Who ranks (or should rank) higher in a presidential administration for succession purposes-the Deputy Secretary of Defense (whose boss, the Secretary of Defense, is fifth in the current statutory order) or the Director of Policy Planning for the State Department (whose boss, the Secretary of State, is third in the current order)? The answer actually may vary depending on the administration and its particular policy focus. Age of

42 See Truman, supra note 37 , at 129 (arguing that in a democracy the chief executive should not have the power to appoint her own successor); see also Wasserman, supra note 1, at 403-09 (rejecting Truman's arguments about the undemocratic nature of succession by cabinet appointees).

43 See Amar \& Amar, supra note 10, at 131; Calabresi, supra note 13, at 173; Wasserman, supra note I, at $406-07$.

44 See Wasserman, supra note 1, at 405-06 (arguing that cabinet officers draw nationwide democratic legitimacy from confirmation by a majority of a popularly elected Senate).

45 See U.S. ConST. art. II, $\$ 2$, cl. 2 ("Congress may by Law vest the Appointment of such inferior Officers, as they think proper, in the President alone, in the Courts of Law, or in the Heads of Departments."). 
department is a useful line when ordering among cabinet officers, all of whom stand on the same level; it is far less useful with regard to lower-level officers, given the numbers and permutations of hierarchy within each department.

This discussion suggests that, while a deeper line of succession might help handle the new worst-case scenario of large-scale destruction of the top tier of the federal government, there is no constitutional or practical basis for any of the possible extensions. The current statute exhausts the existing officers who constitutionally and/or practically can act as president. The current line must be the starting point for any continuity-in-government scheme intended to handle the new mass-destruction contingency.

Congress could expand the number of eligible successors by creating new cabinet departments and cabinet-level officers. Among these new officers could be a designated second successor (after the vice president), one officer whose official job is to become acting president in the event of a double vacancy and whose confirmation process would take into account this specific role. $^{46}$ The First Secretary always would head the shadow government conducting business in the bunker and always would remain behind during the State of the Union Address. At heart, this officer's job would be to stay outside of Washington and away from the president and vice president at all times, ensuring that she would not be killed in any attack on the capital.

New cabinet departments aside, the better approach to this problem is not to expand the universe of successors, but to use the cabinet and legislative officers currently enumerated in the statute in a different order and a different manner.

\section{CONTINUING AND REPOPUlATING THE FEDERAL GOVERNMENT}

The responses to the new worst-case scenario focus on "continuity in government," on keeping the federal government in operation by empowering the remnants, no matter how skeletal, of the original structure. The deceptively simple idea, as President Bush explained, is that "should somebody be successful in attacking Washington, D.C., there's an ongoing government." ${ }^{47}$

\footnotetext{
46 See Amar \& Amar, supra note 10, at 131 (suggesting the creation of the cabinet post of "First Secretary," an officer whose specific and intended role is to serve as contingent successor); see also supra note 16.

47 See Bush, supra note 7, at 317.
} 
Continuity in government raises two distinct but related issues-continuity of the federal government structure and repopulation of federal offices.

\section{A. Continuity in Government}

\section{Of Shadow Governments and Skeletal Congresses}

The most-discussed element of continuity is the "shadow government" plan created by the Bush administration, which has not been explained to Congress or to the public and about which few details are known. The plans apparently involve members of each executive agency and department working on a rotating basis in an undisclosed secure location, preparing to assume power in the event of the complete annihilation of the federal government. The shadow government really is a shadow executive branch and bureaucracy, with no apparent provisions made for continuity either in Congress or the judiciary. This has prompted calls for the other branches to take similar precautions to ensure their own continuity. ${ }^{48}$

Absent from any discussions of the shadow government is mention of a specific head of that government. We do not know whether any provision has been made to ensure that a constitutional or statutory successor to the presidency is present in the bunker at all times. Vice President Cheney apparently has spent a great deal of time since September 11 in undisclosed secure locations. ${ }^{49}$ It also is possible that among the officers working at the undisclosed location at any one time is at least one cabinet officer who would be a proper contingent successor under $\S 19$. Either step ensures some constitutional and structural legitimacy in the continuity government by providing an individual in whom the executive power under the Constitution can be vested. ${ }^{50}$

One glaring problem with the President's continuity plan is that, to the extent Vice President Cheney does not head the shadow government and a

48 See Foley \& Gingrich, supra note 8 (proposing scheme for continuity in House of Representatives and suggesting that Senate continuity would occur through temporary appointments under the Seventeenth Amendment); see also supra note 8.

49 See Bush, supra note 7, at 317 (explaining that Vice President Cheney was staying in undisclosed locations as part of the continuity plans).

50 See U.S. CONST. art. II, \$ I, cl. 1 ("The executive Power shall be vested in a President of the United States of America."); see also Gary Lawson, The Rise and Rise of the Administrative State, 107 HARV. L. REv. 1231, 1242 (1994) ("[T]hat power to execute the laws is vested, not in the executive department of the national government, but in 'a President of the United States of America."'). 
cabinet officer emerges from the bunker, that officer leapfrogs the two legislative officers who (rightly or wrongly) are the proper immediate successors under the current statute. We do not know what role the Speaker or President Pro Tempore plays in the shadow executive branch or whether provision has been made for their security. This might reflect the belief that cabinet officers are more appropriate presidential successors. ${ }^{51}$ It also reflects the practical fact that it is easier to secure the prospective safety of a cabinet officer. The vice president or a cabinet secretary might be able to spend several months incommunicado in a secure location; neither the Speaker nor the President Pro Tempore could do the same, given their responsibilities in Congress and to their constituents in their home states. Assuming that the continuity plans require one proper successor (the vice president or a $\S 19$ officer) in the hideaway at all times, it is more workable for that successor to be a cabinet officer rather than a legislative officer. This practical consideration provides strong additional support for redrafting $\S 19$ to place cabinet officers, beginning with the Secretary of State, at the front of the line of succession. ${ }^{52}$

In the absence of this statutory change, the President's continuity plan creates confusion whenever the secured successor is not the vice president. Imagine a coordinated series of attacks involving ten nuclear devices hidden in backpacks throughout Washington, D.C., killing the president, vice president, and everyone named in $\S 19$ except the President Pro Tempore and the Secretary of Housing and Urban Development, who was taking her turn in the bunker at the time of the attack. The Administration plan assumes that the HUD Secretary will become acting president. But the President Pro Tempore is the rightful acting president under $\S 19 .^{53}$ Who should the public follow? Who should the state governments follow? Who should the remainder of the federal government follow? Most importantly, who should the military obey as Commander-in-Chief and repository of control over the nation's nuclear arsenal and any retaliation plans?

5I See Calabresi, supra note 13, at 156 (arguing for cabinet succession); Wasserman, supra note 1, at 368 (arguing for cabinet succession as the approach most consistent with structural concerns); see also Amar \& Amar, supra note 10, at 114 (arguing that legislative officers are constitutionally excluded from the line of presidential succession). But see Truman, supra note 37, at 129 (arguing that legislative succession is more democratic, because the successor has stood for popular election at some level).

52 See supra notes 17-18 and accompanying text; see also infra notes 149-56 and accompanying text.

53 See 3 U.S.C. § 19(b) (2000). 
This question becomes even more confused in light of the supplantation provision of $\S 19$, which permits the President Pro Tempore-as a "prior entitled individual" under the statute-to replace the HUD Secretary as acting president at any time and for any reason. ${ }^{54}$ Considering the above scenario, we can imagine the HUD Secretary emerging from the secure location as acting president as planned, serving in that role for two weeks, then being supplanted by the President Pro Tempore. Again, who would the people, the states, and the rest of the federal government follow? ? $^{55}$ We can remedy this problem by eliminating the supplantation provisions, which do little more than create mischief in any event. ${ }^{56}$

Larger problems arise in the event that continuity plans make no specific provision for the security of any proper statutory successor. Such a plan might assume that the "federal government" has some meaning and existence apart from the officers chosen via direct or indirect democratic processes. It rests on the view that the executive power need not be vested in any individual because it is vested in the executive agencies and departments themselves. ${ }^{57}$ These agencies and departments properly may continue operating in the wake of the terrorist attack, even absent a president or acting president. A continuity-ingovernment plan premised on that understanding would signal the denouement to the ongoing demise of the unitary executive. ${ }^{58}$ Executive power unquestionably can be delegated by the president to the agencies and departments. ${ }^{59}$ But a continuing executive branch without a president or acting

54 See id. $\$ 19(d)(2)$ (providing that a cabinet officer ceases to act as president after a "qualified and prior-entitled individual is able to act," including the Speaker or President Pro Tempore); see also Brown \& Cinquegrana, supra note 1, at 1437-38; Wasserman, supra note 1, at 366-67.

55 Political partisanship concerns may exacerbate this problem, as the President Pro Tempore is more likely to supplant the HUD Secretary when they are from different political parties. See Wasserman, supra note 1, at 384. Public officials perhaps would put partisan gamesmanship to one side in the wake of a massive attack on the federal government, at least for a while. Or perhaps they would not. In any event, the lack of clarity in the situation, a result both of the supplantation provision and the lack of information about the Bush continuity plan, invites the potential for that very mischief.

56 See Amar \& Amar, supra note 10, at 135 (arguing that the supplantation provisions are unconstitutional and that "[b]umping creates huge problems of logistics and fosters gamesmanship"); Americo R. Cinquegrana, Presidential Succession Under 3 U.S.C. $\$ 19$ and the Separation of Powers: "If at First You Don't Succeed, Try, Try Again," 20 HaSTINGS Const. L.Q. 105, 140 (1992) (arguing that the supplantation provisions serve no legitimate lawmaking purpose).

57 See, e.g., Lawrence Lessig \& Cass R. Sunstein, The President and the Administration, 94 ColuM. L. REv. 1, 54-55 (1994); Thomas O. McGarity, Presidential Control of Regulatory Agency Decisionmaking, 36 AM. U. L. REV. 443, 465-72 (1987).

58 See Lawson, supra note 50, at 1245 (discussing the "death of the unitary executive").

59 See id. 1243-44 n.72. 
president goes one step further by permitting the delagatee to exercise power in the complete absence of any living delegator of that power.

The military raises particular concern. The president herself is Commander-in-Chief of the armed forces, a position at the very heart of the executive power. ${ }^{60}$ Civilian control of the military was understood as a necessary cornerstone of republican government, ensuring the primacy of civil authority over military authority. ${ }^{6}$ Any continuity plans that do not provide for and ensure a proper successor to the presidency are constitutionally infirm in not guaranteeing a civilian Commander-in-Chief, a single individual to maintain civil power and control over the military. ${ }^{62}$ Suppose state and local authorities are unable to keep the peace in the wake of the destructive attack; assuming that declaration of martial law might be an option, ${ }^{63}$ who could exercise the option if there is no acting president at the head of the military to make that declaration? Moreover, how would the armed forces carry out a military response to the terrorist attack in the absence of a civilian at the top of the military hierarchy? It either would be prevented from acting or would act in disregard of civilian control. Neither option is desirable or acceptable.

60 See U.S. CONST. art. II, § 2, cl. 1 ("The President shall be Commander in Chief of the Army and Navy of the United States, and of the Militia of the several States, when called into the actual Service of the United States ...."); THE FEDERALIST No. 69, at 385-86 (Alexander Hamilton) (Clinton Rossiter ed., 1961) (likening the President's power to a governor's power over the state militia, as first general and admiral); see also THE FEDERALIST No. 74, at 415 (Alexander Hamilton) (Clinton Rossiter ed., 1961) ("The direction of war implies the direction of the common strength; and the power of directing and employing the common strength forms a usual and essential part in the definition of executive authority.").

61 See Harold honguu Koh, The national Security Constitution: Sharing Power after the IRAN-CONTRA AFFAIR 77 (1990) (describing the Framers' desire to maintain civilian control over the military); Michael J. Glennon \& Allison R. Hayward, Collective Security and the Constitution: Can the Commander in Chief Power Be Delegated to the United Nations?, 82 Geo. L.J. 1573, 1591 (1994) (arguing that the Commander-in-Chief Clause established unquestioned civilian control over the nation's military); Jonathan Turley, The Military Pocket Republic, 97 Nw. U. L. REv. 1, 22 (2002) ("[T] to keep the military small and subordinate."); see also THE DECLARATION OF INDEPENDENCE para. 14 (U.S. 1776) (enumerating grievances against King of England, including rendering "the Military independent of and superior to the Civil power"); THE FEDERALIST No. 8, at 38 (Alexander Hamilton) (Clinton Rossiter ed., 1961) (describing the concern that the military state would become elevated above the civil state); Turley, supra, at 16 ("[A] wise and prudent people will always have a watchful \& [sic] a jealous eye over it; for the maxims and rules of the army, are essentially different from the genius of a free people, and the laws of a free government." (citation omitted)).

62 Cf. Glennon \& Hayward, supra note 61, at 1593 ("[A]t a minimum[,] the President's Commander in Chief power guarantees him command over the nation's armed forces.").

${ }^{63}$ Cf. Major Kirk L. Davies, The Imposition of Martial Law in the United States, 48 A.F. L. REv. 67, 85 (2000) ("IS]hould civilian agencies become overwhelmed in an environment of chaos and panic, one of the President's obvious options for restoring order would be to declare martial law."). 
The Administration plan also assumes that the executive branch, the federal bureaucracy, and the military can continue to operate in the absence of Congress. Whatever the enhanced power and stature of the modern presidency, ${ }^{64}$ the Constitution still demands that laws be approved by (at least) majorities in both houses and signed by the president. ${ }^{65}$ The primary structural precept of the American constitutional order remains separation of powers, which necessarily assumes some significant role for Congress in the process of governance. ${ }^{66}$ A surviving executive branch cannot alone pass new legislation, appropriate or mint new money, declare war or appropriate funds to fight that war, or carry out many of the responsibilities of governance, powers vested exclusively in Congress. ${ }^{67}$ True continuity of the federal government demands continuity of both political branches; a functioning executive branch cannot alone be sufficient to maintain a functioning national government unless we accept the premise that the terrorist attacks undid the constitutional structure.

Congressional continuity also enables executive continuity. Chances are great that some members of both houses of Congress will survive an attack directed at Washington, given the greater numbers in Congress and the fact that individual members often are away from Washington visiting their home states or districts. Other than an assault directly on the Capitol during full sessions of both houses, it would be difficult to kill 535 members of Congress at once. A working Congress composed of those surviving members ensures the constitutional validity of any post-attack actions taken by the acting

64 See Martin S. Flaherty, The Most Dangerous Branch, 105 YALE L.J. 1725, 1727 (1996) ("Never has the executive branch been more powerful, nor more dominant over its two counterparts, than since the New Deal.").

65 See U.S. CONST, art. I, § 7, cl. 2; INS v. Chadha, 462 U.S. 919, 946-51 (1983) (discussing importance of Bicameralism and Presentment requirements); Lawson \& Seidman, supra note 9, at 6 ("The federal government could not pass laws, appoint officials, or enter into treaties without a Congress, Senate, and a President."); John O. McGinnis \& Michael B. Rappaport, The Constitutionality of Legislative Supermajorify Requirements: A Defense, 105 YALE L.J. 483, 486 (1995).

66 See Calabresi, supra note 13, at 163 ("[W]e must remember that our Constitution is built on a presidential/separation of powers premises . . . ."); Laura S. Fitzgerald, Cadenced Power: The Kinetic Constitution, 46 DUKE L.J. 679, 688 (1997) ("[T]he separation of powers principle serves mostly as a linedrawing tool to mark the boundary between one institution's constitutional tasks and those reserved to another."); Flaherty, supra note 64, at 1819 (describing the president as "legislator-in-chief," drafting bills for Congress to work over and approve); Lawson, supra note 50, at 1239 ("Congress must make whatever policy decisions are sufficiently important to the statutory scheme at issue so that Congress must make them.").

67 See U.S. CONST. art. 1, \$ 8 (enumerating congressional powers); see also Lawson, supra note 50, at 1238 ("The institutions of the national government are creatures of the Constitution and must find constitutional authorization for any action."). 
president and the continuing executive branch, particularly in approving military action and appropriating money to prosecute that war.

Congressional continuity also may guarantee a valid successor to the presidency. Consider a scenario in which the president, vice president, and all cabinet officers, along with the Speaker, President Pro Tempore, party caucus leaders, and most members of both houses of Congress have been killed in coordinated terrorist attacks; 101 House members and 21 Senators remain, along with numerous mid-level executive branch officers. At this point, there is no president and no proper statutory successor who could act as president.

However, both houses of Congress might be able to continue operations with the surviving members. The first operative step in each house will be to choose a new Speaker and new President Pro Tempore. ${ }^{69}$ Both legislators now become legislative officers and designated statutory successors under $\S 19$, either of whom may resign her legislative office and seat and be sworn as acting president. ${ }^{70}$ In other words, the naming of the new Speaker provides the means for naming a new acting president. With this proper individual now acting as president and holding the executive power under the Constitution, any actions by the skeletal executive bureaucracy become constitutionally sound and structurally consistent, with an acting president and a functioning (albeit small) Congress.

Legislative officers are not primary successors under a succession scheme that best conforms to structural principles of separation of powers, political partisanship, and democracy. ${ }^{71}$ However, legislative officers play an important

68 See, e.g., Authorization for Use of Military Force, Pub. L. No. 107-40, 115 Stat. 224 (2001) (authorizing president to use force against terrorist groups in response to September 11 attacks); Foreign Operations, Export Financing, and Related Programs Appropriations Act of 2002, Pub. L. No. 107-115, 115 Stat. 2118 (2002) (appropriating funds for prosecution of War Against Terrorism); Department of Defense and Emergency Supplemental Appropriations for Recovery from and Response to Terrorist Attacks on the United States Act, 2002, Pub. L. No. 107-117, 115 Stat. 2230 (same); Uniting and Strengthening America by Providing Appropriate Tools Required to Intercept and Obstruct Terrorism (USA PATRIOT) Act of 2001, Pub. L. No. 107-56, 115 Stat. 272 (establishing provisions regarding law enforcement, investigation, and prosecution of terrorist activities).

69 See 1 DoCumentary History OF THE FIRST FEDERAL CONGRESS 1789-1791, at 7 (Linda Grant De Pauw et al. eds., 1972) (showing that the United States Senate, having a quorum for first time under the new Constitution on April 6,1789, elected a President of the Senate, for the sole purpose of opening and counting ballots for president of the United States and for continuing business until the vice president was sworn); 3 id. at 7 (showing that House of Representatives, having attained a quorum for the first time under the Constitution on April 1, 1789, immediately proceeded to election of Speaker of the House).

703 U.S.C. $\$ 19$ (a), (b) (2000). See Manning, supra note 30, at 143-45.

71 See Wasserman, supra note 1, at 352. 
role in the more extreme vacancy scenarios now under consideration. If there no longer is a head of the executive branch, the succession line must continue somewhere in the federal government. The two legislative officers whose existence is constitutionally mandated are the best (perhaps only) direction for the succession line to take. ${ }^{72}$ A working skeletal House of Representatives provides that proper successor through the selection of a new Speaker from among its members. ${ }^{73}$ Section 19 should keep the Speaker and President Pro Tempore in the line of succession, eligible to succeed to the White House, but at the end of the line; legislative officers should assume the executive power only if the vice president and every top cabinet officer is dead or disabled.

\section{Quorum Questions}

A related concern is whether the decimated Congress could continue its operations with only 101 House members and 21 Senators. The Constitution provides that "a Majority of each [house] shall constitute a Quorum to do Business." houses, rendering them unable to function as a national legislature, including unable to select a new Speaker or President Pro Tempore, at least until the vacant seats can be filled. ${ }^{75}$

This scenario raises an open constitutional question. The Constitution does not define how the quorum is measured, whether by majority of authorized seats in a house or by majority of occupied seats, of living, already-selected members of each body. In other words, must vacant seats count in the quorum denominator? The skeletal post-attack Congress only can function if the constitutional denominator is based on those 101 living House members, such that House business, including the selection of a Speaker (who then may

\footnotetext{
72 See supra notes $27-46$ and accompanying text.

73 One perhaps could argue that succession by a Speaker chosen by a skeletal 101 -member House is as undemocratic as succession by a rank-and-file House member. See supra notes 27-38 and accompanying text. After all, the former was not really approved by a nationwide constituency, given the small number of House members, perhaps not representing every state, who voted her into the Speakership. Nevertheless, selection into the top position in the House, even if only a skeletal House, grants the Speaker some broader approval than the local electoral support accorded to rank-and-file members. Moreover, this procedure obviates the need for legislation to undertake the impossible task of ranking among states and congressional districts in establishing a succession order. The House chooses a particular individual to be Speaker through its own internal processes and that choice becomes the eligible presidential successor.

74 See U.S. ConsT, art. 1, § 5, cl. 1; see also United States v. Ballin, 144 U.S. 1, 5 (1892); THE FEDERALIST No. 58, at 329 (James Madison) (Clinton Rossiter ed., 1961).

75 See Foley \& Gingrich, supra note 8.
} 
become acting president), can continue when a majority of fifty-one members are present.

The point here is not to resolve the question. The strongest argument for a denominator based on seats actually filled by living members comes from common sense. Common sense dictates that the federal government should not allow itself to be paralyzed by a violent assault directed against government officials. If dead members of Congress whose seats have not yet been filled must be included in the quorum denominator, then a terrorist attack could prevent one or both houses from attaining a quorum, and therefore prevent Congress from functioning, not only in response to the attack itself but also as to the continued needs of governance. To paraphrase Senator Bingham, speaking to the effect of Southern secession on the ratification of the Reconstruction Amendments, it is simply inconceivable that the Constitution enables the planners of a large-scale military or terrorist attack so to interfere with its operation. ${ }^{76}$

Actual practice during the First Congress may provide some guidance." Congress met for the first time on Wednesday, March 4, $1789 .^{78}$ Neither house had a quorum on that date and both adjourned, doing so repeatedly for the next

76 See John Harrison, The Lawfulness of the Reconstruction Amendments, 68 U. CHI. L. REv. 375, 421 (2001) (discussing arguments of Senator Bingham that Southern ratification of the Civil War Amendments was unnecessary because "it is simply inconceivable that the Constitution allows traitors so to interfere with its operation").

77 See David P. Currie, The Constitution in Congress: The Federalist Period, 1789-1801, at 3 (1997) ("II]n a very real sense it can be said that the First Congress was a sort of continuing constitutional convention, and not simply because so many of its members . . . had helped to compose or to ratify the Constitution itself."); 2 Francis Newton Thorpe, The Constitutional History of THE United STATES 1765-1895, at 176-77 (1901) (noting the number of members of the First Congress who had participated in the Constitutional Convention or in the ratifying conventions).

78 See CURRIE, supra note 77, at 3; 2 THORPE, supra note 77, at 176; 1 DOCUMENTARY HISTORY OF THE First Federal Congress 1789-1791, supra note 69, at 3; 3 id. at 3 . That date is understood as the point at which the Constitution came into operation. See Owings v. Speed, 18 U.S. (5 Wheat.) 420, 422 (1820) (holding that the Constitution of the United States came into operation on the first Wednesday in March, 1789); 2 THORPE, supra note 77, at 175 \& n.1. But see Lawson \& Seidman, supra note 9, at 37 (arguing that the Constitution became law over a period of time, as different aspects of the document became active at different points between August 1788 and April 1789). 
month. ${ }^{79}$ The House of Representatives finally attained a quorum of thirty on April 1, the Senate a quorum of twelve on April $6^{80}$

The actions of the Senate during this period are illustrative. On March 11, 1789, the eight present Senators, on behalf of themselves and the eighteen present House members, sent a letter to twelve absent Senators, emphasizing the "utmost importance" of a quorum sufficient to proceed to business, requesting that the absent Senators communicate "information of their situation," and requesting that the absent members attend as soon as possible. This request or compulsion for attendance only could be sent to a Senatorsomeone already selected for his seat and able to assume that position once he presented himself. A letter compelling attendance could not have been sent where the Senate seat had yet to be filled.

The denominator for the first Senate quorum did not include seats for Rhode Island and North Carolina, neither of which had yet ratified the Constitution. $^{82}$ This makes twenty-two the maximum quorum denominator, reflecting the total number of seats in the Senate, requiring twelve for a quorum. However, New York did not select its two Senators until July 1789; the two Senate seats from New York were vacant when the Senate first convened. $^{83}$ Thus, a denominator based only on elected members/occupied seats in March would have been twenty and a majority of eleven would have established a quorum. But the Senate did not deem itself to have a quorum

79 See CURRIE, supra note 77, at 3; 1 DOCUMENTARY HISTORY OF THE FIRST FEDERAL CONGRESS 17891791, supra note 69. at 3 (Senate Journal showing eight Senators present); 3 id. at 3 (Joumal of the House of Representatives, showing 13 Representatives, less than a "quorum of the whole number"); 2 THORPE, supra note 77 , at 176.

80 See 1 Documentary History of The First Federal Congress 1789-1791, supra note 69, at 7 (showing on April 6, 1789 the presence of a "majority of the whole number of Senators of the United States"); 3 id. at 7 (showing on April 1, 1789, in the House of Representatives "a quorum, consisting of a majority of the whole number, being present"); 2 THORPE, supra note 77, at 176.

81 See CURRIE, supra note 77, at 3; 1 DOCUMENTARY HISTORY OF THE FIRST FEDERAL CONGREsS 17891791, supra note 69 at 3-4 \& n.2; 1 id. at 5 (noting a similar letter sent March 18, 1789, to eight absent Senators); see also U.S. CONST. art. I, \& 5, cl. 1 (providing that a number less than a quorum may compel the attendance of absent members). The first letter was addressed to Tristram Dalton, William Paterson, Jonathan Elmer, George Read, Richard Bassett, Charles Carroll, John Henry, Richard Henry Lee, William Grayon, Ralph Izard, Pierce Butler, and James Gunn. See 1 Documentary History OF THE FIRST Federal. CONGRESs 1789-1791, supra note 69, at 4. The second letter was sent to Elmer, Paterson, Read, Bassett, Carroll, Henry, Lee, and Grayson. See 1 id. at 5.

82 See 2 THORPE, supra note 77 , at 177.

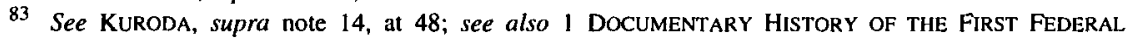
CONGRESS 1789-1791, supra note 69, at 91 (showing the first presentation of Sen. Rufus King of New York on July 25,1789 ). 
when eleven Senators were present on March $28 ;^{84}$ it found a quorum only after a twelfth Senator, Richard Henry Lee of Virginia, presented his credentials on April $6{ }^{85}$ In other words, the First Senate demanded a quorum of a majority of twenty-two possible seats, whether or not those seats had, in fact, been filled.

But consider the mischief that could have arisen during this period if that larger denominator were constitutionally mandated. Although opponents of the Constitution generally fell into line once a given state had ratified, ${ }^{86}$ the influence of Anti-Federalists continued. This risked, in the eyes of Federalists, "much mischief.," In New York, ongoing disagreements between Federalists and Anti-Federalists prevented the legislature from choosing electors to vote in the first presidential election and from selecting Senators until July. ${ }^{88}$ Suppose other states similarly had delayed choosing Senators and Representatives. If those unfilled seats must count in the quorum denominator, the few entrenched opponents of the Constitution could have prevented Congress, and by extension the federal government, from ever transacting business by depriving it of the machinery of governance: a Congress and a president to pass laws and appoint officials. ${ }^{89}$ The Constitution established a majority as quorum specifically to prevent such a minority from scuttling the ability of Congress to act. $^{90}$ The larger denominator, if constitutionally required, would have

84 See $\mid$ DoCumentary History OF THE FIRST FEderal Congress 1789-1791, supra note 69, at 6 (reflecting first appearance of Sen. Jonathan Elmer of New Jersey, an eleventh Senator, but the adjournment of business because of the absence of a quorum).

85 See 1 id. at 6-7

86 See Catherine Drinker Bowen, Miracle at Philadelphia 306 (1966) ("Perhaps this is endemic to America; once the vote is counted, everybody wants to be in the parade.").

87 See 2 THORPE, supra note 77 , at 175.

88 See KURODA, supra note 14, at 39 ("No state offers a better example of how rival political interests and ideas affected the choice of [federal officials] in 1789 than New York, a late, reluctant, and divided supporter of the Constitution."); id. at 48-49 (discussing lessons learned in New York from the long debates and the lack of participation in the first presidential election); id. at 48 (discussing belated selection of two Senators); 2 THORPE, supra note 77, at 177 ("New York, obedient to the influence of [Anti-Federalist Govemor] Clinton, had refused to appoint electors[.]"); see also BOWEN, supra note 86, at 306 (describing New York's grudging, conditions-filled ratification, including suggestion by one Anti-Federalist that New York declare its right to withdraw from the Union after a number of years if suggested amendments were not considered).

89 See 2 THORPE, supra note 77, at 176 ("All through the winter of 1789, the supporters of the Constitution were anxious lest in some way its enemies might yet cause delay, or even overthrow the plan."); Lawson \& Seidman, supra note 9, at 6, 8 (discussing the need for states to select people to operate the machinery of government). The Framers explicitly avoided this problem with regard to the presidency by requiring the president to win only a majority of votes from electors actually appointed. See U.S. CoNST. art. II, $\S 1$, cl. 3. ("The Person having the greatest Number of Votes shall be the President, if such Number be a Majority of the whole Number of Electors appointed ....").

90 See THE FEDERALIST No. 58, at 361 (James Madison) (Clinton Rossiter ed., 1961) (explaining that the 
permitted states, or factions within states, to delay the effectiveness of the Constitution and the ability of the new government to function, contrary to the very purpose of the Quorum Clause.

Another possibility is that the Constitution leaves it to each house to prescribe the method for measuring and determining the quorum and denominator." The current Senate rule requires a "majority of the Senators duly chosen and sworn." provide that during quorum calls the "names of Members" are to be called." The focus on "members" in both rules is logically distinct from "seats" and suggests elected, sworn, living members of the body. It would make little sense for "members" to include vacant seats or nonliving members whose seats had not been filled. At the very least, each house might possess the constitutional power to establish a smaller quorum denominator on the number of living members in occupied seats.

Measuring the quorum by the number of surviving members also obviates one of the stranger and more troubling aspects of the proposal for congressional continuity proffered by former Speakers Thomas Foley and Newt Gingrich. They suggest that the House of Representatives, pursuant to its power to establish rules of proceedings, authorize each member to predesignate an interim successor, who would occupy that seat during the period between the catastrophic loss of House members and the election of a successor. ${ }^{94}$ Their goal is to ensure that the House is able to maintain a quorum during the possibly lengthy interim period. ${ }^{95}$ But if the required denominator is only sworn living House members occupying seats, a small quorum to do business can be attained by the presence of a majority of surviving members,

quorum requirement was set at a majority so that the minority could not wield too much power with regard to the legislature's ability to act); McGinnis \& Rappaport, supra note 65, at $487 \mathrm{n.14}$ (same); see also Records of the Federal Convention, in 2 ThE Founders' CONSTITUTION 289 (Philip B. Kurland \& Ralph Lerner eds., 1987) (quoting arguments from Convention as to a proper legislative quorum).

91 See United States v. Ballin, 144 U.S. 1, 5-6 (1892) (stating that the Constitution requires the presence of a majority, from which the power of each house arises, and that in the absence of guidance from the Constitution, "it is therefore within the competency of the house to prescribe any method which shall be reasonably certain to ascertain" whether a majority is present); see also U.S. CONST. art. I, $\$ 5$, cl. 2 ("Each House may determine the Rules of its Proceedings ...."),

92 See Standing Rules of the Senate No. 108-15, Rule VI, at 4 (2003).

93 See Rules of THE House OF REPRESENTATIVEs, 107th Congress, Rule XX(3), at 29 (2001).

94 See Foley \& Gingrich, supra note 8 . Senate vacancies are filled by gubernatorial appointments. See U.S. CONST. amend. XVII, cl. 2; see also infra notes $133-45$ and accompanying text.

95 See Foley \& Gingrich, supra note 8 (noting that in recent cases it has taken an average of 117 days to fill House vacancies). 
51 of the surviving 101 Representatives. The skeletal House can continue its business and its ability to do so will not depend on immediate replacement of those members killed.

Moreover, the Foley-Gingrich proposal would not be permissible under the Constitution. The power of the House of Representatives to "determine the Rules of its Proceedings" cannot be read as enabling the House to empower each individual member unilaterally to designate a successor, even a temporary one. Each house controls or governs its operations and its business. ${ }^{96}$ But the selection of even interim members has nothing to do with the body's proceedings or operations, and rules of proceeding have nothing to do with the means or manner of selecting Representatives who serve in the House.

In fact, the Constitution establishes two unequivocal means of choosing House members, neither involving action by the House itself. Representatives must be popularly elected by the voters of a district every two years, and vacancies are filled by special elections before those same voters at a time and place established by the state executive. ${ }^{97}$ These are the exclusive methods of choosing House members and neither the states nor Congress may create new or additional mechanisms. ${ }^{98}$ While the House judges whether to seat individual members, ${ }^{99}$ nothing in the Constitution grants it the power to appoint a different, more acceptable member to a seat if it rejects another's credentials or qualifications. Instead, the seat remains vacant. The Constitution also makes no provision for "acting" or "interim" members of the House.

\section{B. Repopulating the Federal Government}

The more important, but unaddressed, procedural issue is how to repopulate the federal government. Imagine, in the most extreme example, that no member of Congress or the cabinet survives; only numerous subcabinet-level, inferior officers remain alive after the terrorist destruction of Washington, D.C. The structural question will be what processes can and

96 See McGinnis \& Rappaport, supra note 65, at 495.

97 See U.S. CONST. art. I, § 2, cl. 1 ("The House of Representatives shall be composed of Members chosen . . . by the People of the several States ...."); id. cl. 4 ("When vacancies happen in the Representation from any State, the Executive Authority thereof shall issue Writs of Election to fill such Vacancies.").

98 Cf. U.S. Term Limits, Inc. v. Thornton, 514 U.S. 779, 796 (1995) ("Congress may not alter or add to the qualifications in the Constitution ...."); id. at 837 (holding that the Constitution enumerates the requirements for election to Congress and that the states lack the power to supplement those requirements).

99 See U.S. CoNST. art. I, § 5, cl. 1 ("Each House shall be the Judge of the Elections, Returns, and Qualifications of its own Members ...."); see also Powell v. McCormack, 395 U.S. 486, 522, 550 (1969). 
should be followed to replace those killed from both political branches, and to bring those branches back to full working capacity. This question properly focuses on operative structural principles, recognizing that the federal government consists of co-equal branches, each of which must be repopulated in order to say truly that the federal government is continuing to perform its governing functions in a constitutionally valid manner.

The current focus on a shadow government derived from remnants of the current executive branch serves President Bush's political purposes of ensuring the American people that there will be some federal government, that the present Administration takes seriously the maintenance of the federal government, and that it is doing something to protect and preserve the Union from attack and tragedy. ${ }^{100}$ Thus the Administration's emphasis is on continuing the existing government in skeletal, incomplete, and arguably unconstitutional form, rather than on selecting replacement officials in all branches through whom the federal government may recover from the attack. This also reflects that the public is not concerned with legal niceties of governmental legitimacy, but with keeping and maintaining some functioning government in place, regardless (at least in the short term) of structure, form, or personnel. ${ }^{101}$

The problem is that the federal government cannot repopulate itself, and its role in repopulation will be limited. Repopulation depends instead on action by the People and by the several states. The People elect new Senators and Representatives. $^{102}$ States appoint temporary Senators to fill vacancies until those new elections. ${ }^{103}$ States establish and control the time, place, and manner for holding congressional elections. ${ }^{104}$

100 See Bush, supra note 7, at 317 ("I have an obligation as the President ... to the American people to ... put measures in place that should somebody be successful in attacking Washington, D.C., there's an ongoing government.").

101 Cf. Lawson \& Seidman, supra note 9, at 25 (arguing that the People in 1788 were not focused on the legal effect of ratification of the Constitution and whether it had created any rights, but "on the concrete problems of putting together a functioning union").

102 U.S. CONST. art. I, \& 2, cl. $1 ; i d$. amend. XVII, cl. 1.

103 See id. amend. XVII, cl. 2.

104 See id art. I, $\S 4$, cl. 1 ("The Times, Places, and Manner of holding Elections for Senators and Representatives, shall be prescribed in each State by the Legislature thereof."); Cook v. Gralike, 531 U.S. 510 , 523 (2001) (stating that the "Elections Clause grants to the States 'broad power' to prescribe the procedural mechanisms for holding congressional elections," in the form of a "grant of authority to issue procedural regulations"). 
This is, in fact, the "true genius of American federalism", 105 applied to modern selection problems. Although the federal government would be the likely target of a terrorist attack, that attack would not eliminate all sovereign power within the nation. The several states continue to exist, each an independent sovereign with inherent and inviolate powers that do not depend for their existence or exercise on the federal government. ${ }^{106}$ These powers include keeping the peace through control of state and local police forces and the National Guard ${ }^{107}$ and maintaining state-controlled infrastructure. These powers also include appointing temporary Senators and controlling the election of new members of both houses, all without any help or control from the federal government. ${ }^{108}$ States are significant in the constitutional order not because they are exempt from federal anti-discrimination laws. ${ }^{109}$ States are significant because they are the entities that guarantee and ensure continuity and reestablishment of the federal government in the aftermath of the attack. Indeed, the theory underlying the Constitution is that the federal government

105 DaVId L. ShapiRo, Federalism: A DIalogue 140 (1995) (describing the "true genius of American federalism" as the opportunity for continued discussion and change of power allocation). See also Ginsberg v. New York, 390 U.S. 676, 708 (1968) (Harlan, J., concurring in part and dissenting in part) ("I would revert to basic constitutional concepts that until recent times have been recognized and respected as the fundamental genius of our federal system, namely the acceptance of wide state autonomy in local affairs."); Chapman v. California, 386 U.S. 18, 48 (1967) (Harlan, J., dissenting) ("To impose uniform national requirements when alternatives are constitutionally permissible would destroy that opportunity for broad experimentation which is the genius of our federal system.").

106 See Steven G. Gey, The Myth of State Sovereignty, 63 Oніо ST. L.J. 1601, 1631 (2002) (“'A] government entity can only be deemed 'sovereign' (in the sense of immediate, rather than ultimate sovereignty) if that govemment's power to adopt policies in a given area is exclusive, if those policies are final, and if the government has the authority to enforce the policies ... 'with evil or pain [or] through fear of that evil."”).

One way in which the terrorist-attack scenario differs from the former Cold War scenario is the survival and continued existence of state governments. The Soviet attack, presumably, would have targeted the nation as a whole on such a massive scale as to destroy all infrastructure at all levels. A terrorist attack or series of attacks likely would be narrower, targeted at the federal government (and Washington), but leaving other levels of government infrastructure in functioning order.

The paradox is that a massive nuclear strike would have laid waste to the entire country, but the advance warning might have allowed for the security of the president and other top officials in the federal government, keeping the national govemment alive. The terrorist scenario leaves in place much of the infrastructure below the federal government, but (due to the element of surprise) may destroy the top of the national government.

107 See Turley, supra note 61, at 21-22 (arguing that state militias were allowed to exist as a continual balance of force between federal and state control).

108 See Lawson \& Seidman, supra note 9, at 11 (" $[\mathrm{T}]$ he states could provide entirely for the election of members of the new Congress without any help from the Confederation Congress."); see also Gey, supra note 106 , at 39 ("[I]f one governmental entity has sovereignty, then by definition the other does not.").

109 See Bd. of Tr. of the Univ. of Ala. v. Garret, 531 U.S. 356, 374 (2001) (holding that states are immune from private civil suits for monetary damages under Americans with Disabilities Act); Kimel v. Fla. Bd. of Regents, 528 U.S. 62, 91 (2000) (same as to Age Discrimination in Employment Act). 
exists because the People, working through the states and state-controlled procedures, choose the highest members of the political branches of government. $^{110}$

We return to a constitutional state of nature, reflecting the period of 1788 1789. The Constitution became effective when New Hampshire became the ninth state to ratify, on June $21,1788,{ }^{\prime \prime}$ and eleven states had ratified by August. $^{112}$ The First Congress, representing eleven states, was seated in March 1789, eight months later. ${ }^{113}$ Presidential electors chose George Washington as President and John Adams as Vice President in February 1789, and both were sworn-in by April. ${ }^{14}$

But nothing about the Constitution or the selection of federal office holders was self-executing. 115 Between August 1788 and March 1789, a "Congress and a President had to be selected" and the "machinery of governance had to be put in place in order for the new national government to function." 116 That eightmonth interim was controlled almost entirely by the states. The lone national action was a law passed by the Continental Congress, providing that electors were to be appointed in the several states by the first Wednesday in January 1789, that electors were to meet on the first Wednesday in February, and that the new Congress would commence proceedings on the first Wednesday in March. ${ }^{17}$ The states did the rest, controlling election or selection procedures for original members of the House, Senate, and Electoral College. ${ }^{118}$ And they

110 See THe Federalist No. 45, at 259 (James Madison) (Clinton Rossiter ed., 1961) ("[E]ach of the principal branches of the federal government will owe its existence more or less to the favor of the State governments."); $i d$. No. 49, at 28I-82 (James Madison) (describing the People as the legitimate source of sovereignty under the Constitution); see also Larry D. Kramer, Putting the Politics Back into the Political Safeguards of Federalism, 100 COLUM. L. REv. 215, 254 (2000) (discussing arguments at the Constitutional Convention that noted the role of the states in creating and selecting the federal government, thus making the states necessary for the very existence of the federal government, and ensuring that the federal government would not endanger those entities on which it depends for its very existence); Lawson \& Seidman, supra note 9, at 11 (stating that there were certain actions in establishing the federal government that the states could complete entirely on their own); Herbert Wechsler, The Political Safeguards of Federalism: The Role of the States in the Composition and Selection of the National Government, 54 ColuM. L. REv. 543, 546 (1954) (arguing that states are the crucial instruments of federal selection).

111 See U.S. ConST. art. VII; Lawson \& Seidman, supra note 9, at 5.

112 See Bowen, supra note 86, at 306.

113 See Lawson \& Seidman, supra note 9, at 6

114 See KURODA, supra note 14, at 38; 2 THORPE, supra note 77, at 177-79.

115 See Lawson \& Seidman, supra note 9, at 5.

116 Id. at 5,8 .

117 See CURRIE, supra note 77, at 3; KURODA, supra note 14, at 28; Lawson \& Seidman, supra note 9, at 6. 11 .

118 See KURODA, supra note 14, at 28-38 (describing efforts and processes in various states to select 
did it in a far more contested political climate, battling intra-state disagreements about the best procedure for selecting presidential electors and Senators, ${ }^{119}$ disagreements about whether Representatives should be chosen by districts or at large, ${ }^{120}$ and general public apathy about the electoral process and the wisdom of establishing a federal government. ${ }^{121}$

In the wake of a massive terrorist attack, the states again must fill two distinct legislative bodies and choose a president, through temporary appointments, direct elections, and selection of presidential electors. It is true that there would be more going on in the nation and the world than in 1788the aftershocks of a massive, possibly nuclear, attack on the lone world superpower; large numbers of dead and injured; the painful and costly process of maintaining order, cleaning up, and recovering from the tragedy; a panicstricken populace simultaneously in mourning and desiring revenge; and a standing military hierarchy equally eager to retaliate. ${ }^{122}$ Popular elections are not easily carried out under such conditions.

On the other hand, states will not have to overcome either public apathy or disagreement about whether to populate the federal government or about whether the federal government is a good idea. It is safe to assume that no state today would engage in delays or abstentions in selecting new representation in the reconstructed federal government. Rather, we can expect the governor of a given state to act to fill Senate vacancies, call elections to fill House vacancies, and to ensure the proper continuity of the national government and of that state's representation in the national government. The point, however, is that the primary locus of repopulation plans and efforts must reside in the several states.

presidential electors and representatives for Congress); 2 THORPE, supra note 77, at 176-77; Lawson \& Seidman, supra note 9 , at 5 .

119 See, e.g., KURODA, supra note 14, at 28-29 (discussing disagreements in New Hampshire); id. at 35-36 (discussing New Jersey and Delaware); id. at 34-35 (discussing Virginia).

120 See id. at 29-30 (discussing disagreement in Massachusetts over whether to choose members of the House of Representatives at large or in districts).

121 See id. at 36-37 (discussing unsuccessful Federalist attempts to stir interest in the elections in Pennsylvania and the report in one county that "no supervisors for the election attended and the people were indifferent to the occasion").

122 See Turley, supra note 61, at 7 ("The modern military is a massive organization that has taken on a broad array of nonmilitary functions while steadfastly preserving martial traditions that predate the Revolution."). 


\section{Changing THE LAW to ACCOMMODATE CONTINGENCIES}

The problem with the President's continuity-in-government plan (besides the fact that no one outside the Administration really knows its content) lies not necessarily with the plan itself. Shadow government is effective in avoiding the most catastrophic scenario by ensuring that some presidential successor and some portion of the executive branch is secure at all times and will survive a terrorist attack. The problem is the way in which the plan fits (or does not fit) with constitutional requirements for selecting members of the executive and legislative branches, the meaning of the Succession Clause, and general structural principles of separation of powers, democracy, and political partisanship. $^{123}$

It often is necessary to rework the overarching structure in order to accommodate previously unanticipated contingencies. In fact, a key purpose of the Article $\mathrm{V}$ constitutional amendment process is to address situations where experience suggests that existing procedures do not operate effectively or properly in light of developments and circumstances that the Framers did not or could not foresee. ${ }^{124}$

The best prior illustration of this point is the Twelfth Amendment. The original Electoral College scheme called for each elector to cast two votes for president, with the top vote recipient becoming president and the runner-up becoming vice president. ${ }^{125}$ This scheme assumed there would be no party system and that the two most qualified candidates together would form the executive branch. ${ }^{126}$ However, political parties quickly developed under the new Constitution, bringing with them the practice of informally designating one candidate as the choice for president and one as the choice for vice president and instructing electors to vote accordingly. ${ }^{127}$

123 See Wasserman, supra note 1, at 347-51 (describing structural principles and their role in devising and operating governmental selection procedures).

124 THE Federalist No. 43, at 246 (James Madison) (Clinton Rossiter ed., 1961) ("That useful alterations will be suggested by experience could not but be foreseen."); Kathleen M. Sullivan, Constitutional Constancy: Why Congress Should Cure Itself of Amendment Fever, 17 CARDOZo L. REV. 691, 692-93 (1996) (arguing that only two constitutional amendments have "worked significant structural changes in the original constitutional framework").

125 U.S. ConST, art. II, \$1, cl. 3. See KURODA, supra note 14, at 172; Sanford Levinson \& Emest A. Young, Who's Afraid of the Twelfth Amendment?, 29 FLA. ST. U. L. REv. 925,928 (2001).

126 See KURODA, supra note 14, at 27; Levinson \& Young, supra note 125, at 928.

127 See KURODA, supra note 14, at 129. 
The pre-Twelfth Amendment system prevented parties from filling both offices with their chosen candidates under ordinary procedures in both 1796 and 1800. The election of 1796 produced a divided executive-Federalist President John Adams and Republican Vice President Thomas Jeffersonbecause Federalist electors withheld votes from the party's vice presidential favorite in order to avoid a tie. ${ }^{128}$ The election of 1800 produced a tie between the top two Republican vote recipients, a contingency election in the House of Representatives, and very nearly an inversion of candidates-vice presidential choice Aaron Burr as president instead of the party's presidential choice, Thomas Jefferson. ${ }^{129}$ It also produced "a fiasco that threatened to become a full-fledged constitutional crisis."

The Twelfth Amendment followed, establishing separate candidates, ballots, and votes for each executive office, eliminating the risk of an inversion of candidates, and significantly decreasing the risk of a split executive. ${ }^{131}$ The Amendment brought formal constitutional selection mechanisms in line with informal party practices by making those party practices the constitutional norm. That is, Congress recognized a deficiency in constitutional procedures in connection with a particular development (the rise of political parties) and it adjusted procedures to conform to and function within that new development.

The Framers similarly never imagined the possibility that every top-level official in both political branches could be killed in a single attack or series of coordinated attacks. The solution, however, is not President Bush's unilateral continuity plans that assume an executive branch moving forward without a legislative branch or an acting president at its head. Nor is the solution for members of Congress to arrogate to themselves baseless powers to appoint temporary replacements, as Foley and Gingrich propose. ${ }^{132}$ To the extent current structures are unable to handle the mass-destruction scenario that some believe possible after September 11, the solution must incorporate constitutional amendments and revised statutory schemes that allow for valid succession and continuity.

\footnotetext{
128 See id. at 65-71; Akhil Reed Amar \& Vik Amar, President Quayle?, 78 VA. L. REV. 913, 921 (1992); Levinson \& Young, supra note 125 , at 928.

129 KURODA, supra note 14, at 99; Amar \& Amar, supra note 128, at 922; Levinson \& Young, supra note 125 , at 929.

130 Levinson \& Young, supra note 125, at 928.

131 See U.S. ConST. amend. XII; see also Amar \& Amar, supra note 128, at 922-23.

132 See supra notes $94-99$ and accompanying text.
} 
Presidential succession and continuity-in-government plans arise in highstakes circumstances, suggesting the need to make specific changes to succession provisions rather than risking a national crisis should a mass attack on, and destruction of, the highest levels of the federal government actually occur. Again, while the People will not focus on legal and constitutional technicalities, any continuity scheme, particularly with regard to presidential succession, should produce a government and government officials who are unquestionably legitimate and constitutional. ${ }^{133}$

\section{A. Constitutional Amendment}

\section{Temporary House Appointments}

The Constitution should be amended to allow states to make temporary appointments to fill vacancies in House seats, just as they make temporary appointments to fill Senate vacancies. ${ }^{134}$ The amendment would authorize the legislature of each state to empower the governor to make the appointment and for the appointee to serve until writs of election are issued and a new representative can be elected.

Foley and Gingrich are correct that generally long delays in holding special congressional elections create problems under the mass-destruction scenario, necessitating such short-term appointments. ${ }^{135}$ The exigencies of a mass destruction might speed the election process, as states push forward in recognition of the unique emergency, with or without guidance from Congress. We also could expect state and local officials, already well-known in their districts, to step up and stand for election. On the other hand, an election might be difficult in the post-attack climate; temporary appointments, which can be made in a matter of days with state and local officials willing to step into the breach, become the best option for repopulating both legislative houses as quickly and easily as possible.

\footnotetext{
133 See Amar \& Amar, supra note 10, at 139; see also Manning, supra note 30, at 153 ("[A] law for times of exigency should be free of doubt.").

134 Compare U.S. CONST. amend. XVII, cl. 2 ("When vacancies happen in the representation of any State in the Senate, the executive authority of such State shall issue writs of election to fill such vacancies: Provided, That the legislature of any State may empower the executive thereof to make temporary appointments until the people fill the vacancies by election as the legislature may direct."), with id. art. I, $\S 2$, cl. 4 ("When vacancies happen in the Representation from any State, the Executive Authority thereof shall issue Writs of Election to fill such Vacancies.").

135 Foley \& Gingrich, supra note 8.
} 
Temporary House appointments remain necessary even if there can be a quorum and selection of a new Speaker by the skeletal House. ${ }^{136}$ The Constitution must handle the most extreme situation-the death of every single member of the House, which obviously eliminates any chance at a quorum. In the extreme, states could appoint representatives to an entirely new House, who then form a quorum and choose a Speaker, who then could resign her House seat and act as president, if necessary. Moreover, even if a quorum is possible with a majority of 101 surviving House members, this amendment would help avoid long periods with a small, skeletal House of Representatives that may not include representation for all states. Temporary appointments, which bring the House to full capacity, meet that need.

Foley and Gingrich want to give the appointment power to the current occupant of each House seat, rather than to the governor acting on the authority of the state legislature. They argue that it is more democratic to have the elected representative determine her own temporary successor, that it grants the successor a type of apostolic legitimacy, having been hand-picked by the popularly elected Representative. ${ }^{137}$ The governor's statewide electoral constituency may be significantly different than the more local constituency of a House member from one part of the state..$^{138}$ The result might be an appointee very different from the type of candidate who would be elected from that district. Further, Foley and Gingrich suggest that it is more consistent with political partisanship concerns, as it ensures that a Democrat will designate a Democratic successor, whereas a Republican governor might appoint a Republican successor to a seat formerly held by a Democratic representative. ${ }^{139}$

Both democracy and political partisanship are vital structural considerations in establishing and operating selection procedures. ${ }^{140}$ But one reason that President Truman and Congress placed elected legislative officers, rather than appointed cabinet officers, at the head of the succession order when $\S 19$ was amended in 1947 was the belief that it was undemocratic to appoint one's own contingent successor. ${ }^{141}$ Actually, the president does appoint her contingent successor in two situations-in choosing a vice presidential running

\footnotetext{
136 See supra notes 74-99 and accompanying text.

137 See Foley \& Gingrich, supra note 8.

138 See Fitzgerald, supra note 66, at 749 (describing the "more polyglot character" of the statewide electoral constituency).

139 See Foley \& Gingrich, supra note 8.

140 See Wasserman, supra note 1 , at 348-51.

141 See Truman, supra note 37, at 129; see also Wasserman, supra note 1, at 356, 407 (describing Truman's arguments in favor of legislative succession to the presidency).
} 
mate and in appointing a new vice president to fill a vacancy in that office under the Twenty-fifth Amendment. ${ }^{142}$ Importantly, however, neither appointment is unilateral. An appointee to a vacant vice presidency must be confirmed by a majority of both houses of Congress. ${ }^{143}$ And a candidate for vice president stands before the electorate as part of the presidential candidate's ticket. Voters cannot cast a separate vote for vice president, ${ }^{144}$ and it is unlikely that the vice presidential candidate's presence will affect the decision to vote for the presidential candidate at the head of the ticket. ${ }^{145}$ Nevertheless, the vice president still stands before the national electorate for some consideration.

By contrast, having the holder of a federal congressional seat, once elected, unilaterally tap a contingent successor to her seat is entirely novel. There is no hint of popular consideration of that successor or her qualifications. And there is no hint of popular accountability for the selection of that successor; the People cannot do much to hold a deceased member of Congress accountable for her choice. A president could, in theory, be held to account for a poor vice presidential choice. Similarly, a governor remains accountable if an appointee to a House vacancy proves unpopular. This accountability also reduces the risk of blatant partisanship in House appointments. A Democratic governor who, in the wake of a terrorist attack, appoints ten Democrats to replace an evenly split House delegation might pay a political price.

Temporary House appointments likely have been considered unnecessary, given the relatively short two-year term of office; by the time a temporary appointee is in place and writs of election have been issued, the regular biennial election has arrived. This perhaps explains why the Seventeenth Amendment, in providing for popular election of Senators and temporary appointments until an election could be held, did not provide for similar appointments in the House. The mass-destruction scenario, with simultaneous vacancies in so many seats, alters the analysis, making temporary appointments vital both to ensure a quorum to do business and a close-to-full, more

\footnotetext{
142 See Wasserman, supra note 1, at 407-08 (describing two situations in which the president appoints the vice president, who is the immediate constitutional successor).

143 U.S. CONST. amend XXV, \& 2.

144 See Amar \& Amar, supra note 128, at 925-26 (describing state election laws under which names of the presidential and vice presidential candidates of one party are listed as a single party ticket on the ballot); id. at 913 (noting the inability of voters to split the executive ballot).

145 See id. at 926 ; see also id. at 916 (stating that in 1988, many voters would have preferred to vote for an executive branch of Republican presidential candidate George H.W. Bush and Democratic vice presidential candidate Lloyd Bentsen).
} 
representative House during the interim between the tragedy and any special election.

\section{Clarify the Meaning of the Word "Officer" in the Succession Clause}

The Succession Clause of Article II, section 1 should be amended to make clear that legislative officers are constitutionally eligible statutory successors, that the Speaker and the President Pro Tempore are legislative officers, differently situated from rank-and-file legislators, and that they are officers constitutionally eligible to act as president. ${ }^{146}$ Doing so removes any doubt as to the constitutionality of the Speaker or President Pro Tempore acting as president. This change is necessary because, while neither legislative officer should be at the head of the line of succession, the Constitution must account for every member of the cabinet being killed in the terrorist attack. The executive power must devolve to legislative officers in that situation; the Constitution clearly should provide that such limited legislative succession is valid.

But the Succession Clause still should be limited to "officers"-meaning cabinet members, the Speaker, and the President Pro Tempore-and no one else. The line of succession should extend no further, given the strong democratic and practical arguments that preclude placing rank-and-file members of Congress or state governors in the line of succession. ${ }^{147}$

\section{Emergency Quorum}

The Quorum Clause should be amended to make clear that it is permissible for either house to establish as the quorum denominator the number of seats currently occupied by living members, rather than total number of authorized seats, as an emergency measure. ${ }^{148}$ This guarantees that the skeletal 101-person House and 21-person Senate can continue to perform legislative functions until vacant seats can be filled, whether by appointment or election.

\section{B. Statutory Changes}

The mass-destruction scenario provides an incentive for Congress and the president to make several necessary changes to the statutory succession

146 See Manning, supra note 30, at 143; see also supra notes 27-33 and accompanying text.

147 See supra notes 34-41 and accompanying text.

148 See infra notes 170-74 and accompanying text. 
process. Such changes bring $\S 19$ in line with the amended constitutional text and structural principles and enable the statutory scheme better to handle a worst-case scenario.

\section{Change the Statutory Succession Order}

The first and most important change is to the enumerated succession order. The executive power should devolve into the cabinet first, beginning with the Secretary of State and proceeding according to age of department. ${ }^{19}$ The Speaker and President Pro Tempore should remain in the line of succession, but at the end, assuming the executive power only in the event of total destruction of the executive branch. This is a statutory concession to the massdestruction exigency. While previous arguments had urged removing legislators from the succession line altogether ${ }^{150}$ the new scenario assumes the possibility of the destruction of the entire cabinet. The line of succession must extend to Congress, which in turn can ensure the provision of a proper successor. ${ }^{151}$

\section{Eliminate Supplantation}

Second, Congress should eliminate the supplantation provision, under which a prior-entitled statutory successor may supplant a lower statutory officer who already has been sworn-in as acting president. ${ }^{152}$ The provision does little more than bring about confusion and in-fighting among statutory successors. ${ }^{153}$

The only situation in which some form of supplantation remains necessary is where the president has been killed, the vice president temporarily disabled, and the Secretary of State has become acting president. Once the vice president no longer is disabled, she assumes the executive power from the Secretary. However, no statutory provision is needed to accommodate this situation. Because the president is dead, the vice president becomes president; $;{ }^{154}$ the Secretary of State has become acting president only because

\footnotetext{
149 See Amar \& Amar, supra note 10, at 135-38; Calabresi, supra note 13, at 156; Wasserman, supra note 1 , at 409.

150 See Wasserman, supra note 1, at 409; supra notes 17-18 and accompanying text.

151 See supra notes $68-73$ and accompanying text.

1523 U.S.C. $\$ 19$ (d)(2) (2000).

153 See supra notes $54-56$ and accompanying text.

154 U.S. CONST. amend. XXV, § 1 ("In case of the removal of the President from office or of his death or resignation, the Vice President shall become President.").
} 
the vice president is disabled. As a constitutional matter, the Secretary acts as president only until the vice president's "Disability be removed." 155 Thus, once the vice president (now the president) is no longer disabled, she is constitutionally mandated to resume the presidency; any statutory declaration of that fact is superfluous. Beyond this situation, once any $\S 19$ statutory successor has been sworn-in as acting president, she should remain in that position until the selection of a new president. ${ }^{156}$

\section{Special Presidential Election}

Third, Congress should amend $\S 19$ to provide for a special election to select a new president and vice president as quickly as possible whenever anyone below the vice president assumes the presidency. ${ }^{157}$ This election will produce a president (as opposed to an acting president), meaning it must be conducted as any ordinary presidential election, with executive officers chosen by presidential electors selected according to mechanisms established in each state. $^{158}$ All states have decided on popular election as the means of choosing those electors, ${ }^{159}$ although each state does remain free to utilize a different procedure for choosing electors for the special presidential election. ${ }^{160}$ Assuming that most states recognize the democratic import of popularly selecting electors, ${ }^{161}$ the special election will operate as fifty-one simultaneous state-controlled popular votes for presidential electors.

155 Id. art. II, \& 1, cl. 6 (“'SS]uch Officer shall act accordingly, until the Disability be removed . ..."). See also Amar \& Amar, supra note 10, at 135-36.

156 See Amar \& Amar, supra note 10, at 135 (arguing that the Constitution does not permit a statute under which some officer acts as president until some other enumerated officer (other than the vice president) wants the job).

157 See id. at 138; Calabresi, supra note 13, at 174; Wasserman, supra note 1, at 409-10.

158 U.S. CONST. art. II, \& I, cl. 2-3, amended by U.S. ConST. amend. XII. See Bush v. Gore, 531 U.S. 98 104 (2000) (per curiam)

159 See Bush, 53I U.S. at 104 ("History has now favored the voter, and in each of the several States, the citizens themselves vote for Presidential electors."); Wasserman, supra note 1, at 396 ("All of the states have adopted ... popular election as the means of choosing presidential electors[.]").

160 See U.S. Const. art. II, $\$$ I, cl. 2 ("Each State shall appoint, in such Manner as the Legislature thereof may direct, a Number of Electors ...."); Bush, 531 U.S. at 104 (noting that the state can take back the power to appoint electors at any time); Wasserman, supra note 1, at 400 ("The Constitution gives the states plenary power to determine the manner of appointing electors and nothing suggests any limitation on that power ..."). Bur see Peter M. Shane, Disappearing Democracy: How Bush v. Gore Undermined the Federal Rig/t to Vote for Presidential Electors, 29 FLA. ST. U. L. REv. 535, 549 (2001) ("It is unthinkable, against this history of constitutional development, that a state legislature should still be deemed authorized to usurp the people's role in choosing presidential electors.").

161 See Wasserman, supra note 1, at 396-97 (arguing that the prevalence of popular selection of electors has made the president a more democratic officer); see also Shane, supra note 160, at 539 ("[T]he Fourteenth Amendment, persuasively read, does guarantee individual citizens the right to vote for presidential electors.”). 
The special presidential election is vital because the annihilation of the top levels of the federal government shakes the federal system to its foundations. Effective continuity in the executive branch in the long term demands a president, rather than an acting president. There is a symbolic benefit to having a president at the head of the executive branch in time of crisis, both for the office holder and the People. ${ }^{162}$ Moreover, the special election places the direct popular imprimatur of the national electoral constituency on the new occupant of the White House as she begins the process of leading the federal government and the nation back from tragedy. ${ }^{163}$

In addition, the speedy special election obviates the need for supplantation among statutory successors. While the Secretary of State is a more preferable successor than the Secretary of Veterans' Affairs or the Speaker of the House, the special election means that any statutory successor, no matter how high or low on the list, will act only for a matter of months. It is not worth the uncertainty (and the potential for manipulation and abuse) ${ }^{164}$ in a time of crisis to have cabinet officers fighting amongst themselves over who properly should be acting as president. A special election makes it easier for Congress to eliminate supplantation.

The acting president, whether elevated from the cabinet or Congress, should help restore order, provide emergency relief, and keep the peace in the immediate aftermath of the tragedy, then give way to a duly elected president, who will serve the remainder of the extant four-year term. That election can and should occur within six or seven months, if not sooner. ${ }^{165}$ The president chosen in the special election will serve only the remainder of the unexpired term and the next regular quadrennial presidential election should occur on

162 See Wasserman, supra note 1, at 410-12 (describing benefits of electing a president as quickly as possible, including the symbolic benefit of removing the word "acting" from in front of the title).

163 See id. at 412; see also Akhil Reed Amar, Presidents Without Mandates (With Special Emphasis on Ohio), 67 U. CIN. L. REv. 375, 384 (1999) (emphasizing the need for "a strong mandate from the American people" and "a leader who does have such a mandate to hold the nation's (and today, the world's) most powerful office").

164 See Cinquegrana, supra note 56, at 139 ("The looming omnipresence of a congressional power to supplant an Acting President would so clearly prevent the uninhibited performance of those functions as to require no further elaboration."); id. at 117-19 (describing elaborate hypothetical in which the Speaker uses the underlying threat of supplantation to compel the acting president to appoint an independent counsel to investigate cabinet officers); Wasserman, supra note 1, at 366-67 (describing possible manipulation of supplantation power and resulting loss of executive independence); see also supra notes 55-56 and accompanying text.

165 See Amar \& Amar, supra note 10, at $138 \mathrm{n} .144$ (arguing that allowing time for grieving and campaigning would mean that a special election could not be held for six or seven months); Calabresi, supra note 13, at 174 (arguing for special election within 60 days). 
schedule. ${ }^{166}$ If the mass-destruction occurs during a presidential election year, no special election is necessary, and the scheduled election should proceed.

\section{Special Congressional Elections}

Fourth, Congress should require that any Senate seat recently filled by appointment be contested in an immediate special election, whenever some certain number of Senate seats (for example, when one-fifth of the Senate, or twenty seats) are filled by recent appointees. Although the power to issue writs of election to fill Senate seats rests with the state, ${ }^{167}$ Congress may by law establish uniform rules for national elections. ${ }^{168}$

An appointed Senator, like an acting president, should not serve all or a substantial portion of a lengthy term; democracy demands a duly elected legislator in office as quickly as possible. Senate appointees ordinarily serve only until the next statewide election, usually held within two years. But if every state will be conducting a special presidential election within six months of the attack, it makes sense to select permanent Senators during the same procedure. $^{169}$ This again limits the amount of time in which an elective office is occupied by an unelected official.

House seats, having been filled by state appointees, also could be contested at this election, although there perhaps is less need to elect new House members at this point, since each House seat will be up for election within two years in any event. Imagine the following-the mass terrorist attack occurred six months into a new Congress, the appointee was placed in the seat within one week, and the special election occurred six months later, approximately one year into a two-year term. That seat will be contested again in a regular election less than one year later. This contrasts with an acting president, who may serve as long as three more years or an appointed Senator, who may serve as long as five more years. There are fewer democratic problems with an

166 See Wasserman, supra note 1, at 410 (arguing that the democratic and partisan flow to the pattern of presidential and congressional elections, in which the President, all of the House, and one-third of the Senate stand for election together every four years, should remain in place even after the special presidential election). In a similar fashion, a vice president who becomes president remains president only for the remainder of the ongoing term, rather than beginning a new four-year term. See Amar \& Amar, supra note 10, at 138 n.144.

167 See U.S. ConST. amend. XVII, cl. 2; id. art. I, \& 4, cl. 1 ("The Times, Places and Manners of holding Elections for Senators and Representatives, shall be prescribed in each State by the legislature thereof .....").

168 See id. art. I, § 4, cl. 1 (“Congress may at any time by Law make or alter such Regulations ....").

169 The congressional election should occur even if there is no need to select a President, as where the vice president was in the bunker and survived the terrorist attack. Democratic concerns still demand elected Senators as quickly as possible, at least where some critical mass of Senate members are appointees. 
appointed House member serving out the brief remainder of the term for the seat to which she was appointed.

\section{Special Small Quorum Rules}

Fifth, each house of Congress should promulgate, pursuant to the power to establish its own rules of proceeding, a special quorum rule that clearly defines a quorum as a majority of the number of seats presently occupied by sworn living members. This rule ensures that, in the hours and days following any mass destruction, Congress can assemble and continue its operations in a constitutionally consistent and proper manner, thereby enabling the federal government as a whole to continue its operations in a constitutionally consistent and proper manner. This will be an emergency rule, applicable only in the event of a mass catastrophic attack that kills a large number of members of Congress, a determination made by each house of Congress.

The fact that this quorum might be small-not much larger than the quorum of thirty out of fifty-nine House members with which Congress began in $1789^{170}$-perhaps is problematic. There were objections at the Constitutional Convention to the small size of the House of Representatives, a fear that a small legislative body is a poor depositary of the public interest, lacking necessary knowledge of constituents' interests. ${ }^{171}$ Similar doubts might arise with the post-attack skeleton House. Having the House of Representativesthe department of the federal government closest to and most dependent on the People ${ }^{172}$ - shrink from 435 to 101 members (with some states perhaps lacking any representation) and continuing to act as a national legislative body with a quorum of just fifty-one, raises doubts about the broader democratic legitimacy of its actions. ${ }^{173}$ There also could be some limit as to how low this special quorum could go-the two Senators from North Dakota and the one House

170 North Carolina, which had five seats, and Rhode lsland, which had one seat, had not yet ratified the Constitution at the time the House began operations in April 1789.

171 See The Federalist No. 55, at 309 (James Madison) (Clinton Rossiter ed., 1961); id. at 312 ("[T]he liberties of America cannot be unsafe in the number of hands proposed by the federal Constitution."); $i d$. No. 56, at 314 (James Madison) (addressing charge that House would "be too small to possess a due knowledge of the interests of its constituents").

172 See The Federalist No. 52, at 295 (James Madison) (Clinton Rossiter ed., 1961) ("[I]t is particularly essential that the [House of Representatives] should have an immediate dependence on, and an intimate sympathy with, the people.").

173 See Adrian Vermeule, The Constitutional Law of Congressional Procedure 32-33 (2003) (unpublished manuscript on file with the author) (describing as one arguable cost of legislative absence "the loss of legitimacy said to result when the legislature proceeds without a full complement or even majority participation"). 
member from Delaware arguably should not alone be enough to engage in valid legislative activity.

The small size of this quorum is the product of the extreme emergency and should be only temporary, lasting until vacancies can be filled by the several states through immediate appointments and by the People through statecontrolled elections. As Madison argued at the beginning, it cannot be thought that "the smallness of the number, as a temporary regulation, be dangerous to the public liberty[.]"174 And assuming speedy appointments by state governors, the skeletal Congress will be acting only for a few days before the membership of each house is brought up to full working capacity.

One perhaps could argue that appointing new members to both houses obviates the need for a special quorum; assuming sufficient appointments can be made within a matter of days, each house can reestablish a full quorum, leaving Congress unable to assemble and conduct business only for a short period. This assumes, however, that some valid form of the executive branch remains in place to manage the situation and carry out existing law, even if no new legislation or appropriations will be forthcoming in that first week. This, in turn, assumes that some eligible statutory presidential successor survived the attack and validly holds the executive power under the Constitution. But if none of the prior enumerated officers survives, the skeletal Congress must have the ability to act immediately to select a new Speaker, who in turn will become acting president. ${ }^{175}$ Congress cannot be made to wait even a week to allow for sufficient state appointments, because no one would be in place to assume the executive power in the meantime.

\section{Arrange for Assembly Away from the Seat of Government}

A final consideration is where the shadow government, in whatever form, will meet, assuming that Washington, D.C. has been destroyed or rendered uninhabitable by a terrorist attack. All government activity must occur in Washington, "the seat of government .. . and not elsewhere, except as otherwise expressly provided by law." ${ }^{176}$ Congress has empowered the president to convene Congress and to conduct other government operations elsewhere in case of the prevalence of a contagious disease or sickness at the

\footnotetext{
174 See The FederalisT No. 55, at 311-12 (James Madison) (Clinton Rossiter ed., 1961) (emphasis added).

175 See supra notes $68-91$ and accompanying text.

1764 U.S.C. \& $72(2000)$.
} 
seat of government or, in the case of Congress, "other circumstances . . . hazardous to the lives or health of the members." to the rest of the federal government should also include "other hazardous circumstances" language, so both political branches of the government can be relocated to a safe, habitable location from which to conduct business. ${ }^{178}$

\section{Respective Roles of Federal and State Governments}

The last consideration for repopulation of the federal government is the respective balance of power between the state and federal governments. The primary locus of repopulation activity will be the several states. ${ }^{179}$ States control the means of appointing members to both the House and Senate, including the identity of those temporary appointees. States control the special elections for the House and Senate and the process for choosing presidential electors, whether the legislature retains for itself the power to appoint electors or provides for selection by special popular election. States execute these selection processes without guidance or control from the federal government.

The federal government's role will be limited to establishing more specific, uniform requirements to guide states in the repopulation efforts. Congress should demand, for example, that each state provide for temporary appointments within seven to fourteen days. Perhaps Congress could require each governor to prepare an advance list of possible appointees for each seat in its congressional delegation, probably from among state and local officers willing to agree to accept that appointment in the emergency. This advance list of potential appointees also restores some popular accountability. Assuming the list becomes public, the People perhaps could take a governor to task in advance if the proposed appointees are unpopular or unqualified.

177 Id. $\$ 73$ ("In case of the prevalence of a contagious or epidemic disease at the seat of government, the President may permit and direct the removal of any or all the public offices to such other place or places as he shall deem most safe and convenient for conducting the public business."); 2 U.S.C. § 27 (2000) ("Whenever Congress is about to convene, and from the prevalence of contagious sickness, or the existence of other circumstances, it would, in the opinion of the President, be hazardous to the lives or health of the members to meet at the seat of Government, the President is authorized, by proclamation, to convene Congress at such other place as he may judge proper.").

178 A relatively minor point such as the place of seat of government in the event of the anticipated emergency illustrates the import of an open and more comprehensive approach to the question of continuity in government, an approach that considers all contingencies and all branches of the federal government; this contrasts with the apparently narrow and unilateral approach taken by the Bush Administration. See supra note 8 and accompanying text.

179 See supra notes $100-22$ and accompanying text. 
The federal government can also establish some more specific, uniform requirements as to when expedited special elections should take place and how they should be carried out. ${ }^{180}$ Congress could require states to prepare detailed contingency blueprints for a quick cold start to the state election machinery. It should demand, for example, that all special presidential or congressional elections occur and all presidential electors be chosen within six months of the catastrophic event. Finally, Congress's main function will be to determine the time and manner in which the electors, once chosen via state-controlled procedures, cast votes for the new president and vice president and the time and manner in which those votes will be counted and recorded. ${ }^{181}$

\section{Continuity and Repopulation in Practice}

With the suggested constitutional and statutory changes in place, how would succession and continuity work in the wake of a massive terrorist attack that took out the top levels of the federal government?

First consider presidential succession. If the vice president survives, she becomes president and appoints a new vice president. If the vice president does not survive and a cabinet officer does, she becomes and remains acting president; a surviving Speaker or President Pro Tempore remains in Congress. If no cabinet officer survives, the executive power devolves (properly, thanks to the constitutional amendment) to the Speaker or to the President Pro Tempore.

In a more extreme example-the president, vice president, the entire cabinet, the Speaker, and the President Pro Tempore all killed, 101 House members and 21 Senators remain-succession works as follows: The skeleton Congress selects a new Speaker and a new President Pro Tempore; each house has a quorum to do this under its emergency rule utilizing living members in occupied seats as the denominator. The new Speaker resigns her seat and the Speakership and becomes acting president. The House, now 100 members

180 See U.S. CONST. art. I, $\S 4$, cl. 1 (providing that Congress may make or alter regulations as to the time, place, and manner for choosing Representatives and Senators); id. art. II, $\S 1$, cl. 4 ("The Congress may determine the Time of chusing the Electors, and the Day on which they shall give their Votes; which Day shall be the same throughout the United States.").

181 Cf. 3 U.S.C. $\$ 7$ (2000) (providing date on which electors meet for ordinary presidential election); $i d$. $\S 8$ (providing that electors vote "in the manner directed by the Constitution"); id. $\S 9$ (establishing certification procedures after elector votes); id. $\$ \S 9-12$ (providing for certification and reporting of results of elector votes to Congress); id. $\$ \S 15-18$ (establishing procedures for congressional counting and challenging of electoral votes). 
strong, selects a new Speaker. The acting president appoints a new cabinet and begins fully exercising the executive power under the Constitution until the special election.

As for congressional continuity, both houses continue operations under the new, small-quorum rules. A majority in each-fifty-one in the House, eleven in the Senate-enables Congress to continue as an effective legislative body. Governors appoint temporary replacements to the vacant seats in both houses, preferably within one to two weeks. Within a matter of weeks, each house should be back at or close to capacity and with a true working quorum based on a majority of possible members.

Within six months, a special election will occur for the Senate, perhaps the House, and for presidential electors, if someone other than the vice president has assumed the presidency. ${ }^{182}$ This election will be the last phase of continuity-in-government. When the election is over, a president and vice president will be in office and both houses of Congress will be at full capacities of 100 and 435 (with quorums of 51 and 218, respectively), with all members popularly elected.

Finally, we consider the most extreme scenario-president, vice president, entire cabinet, and all of Congress killed in the attack. ${ }^{183}$ The real problem here will be the delay and the power vacuum. The states must immediately, within a matter of days, appoint new Representatives and Senators. Both houses will assemble with these newly appointed members and choose a Speaker and President Pro Tempore, respectively. The Speaker now is statutorily eligible to act as president ${ }^{184}$ once she resigns the Speakership and her House seat. The acting president appoints cabinet officers to help her carry out the executive power, most importantly in keeping the peace, beginning emergency relief efforts, and planning any military retaliation. The House chooses a new

182 A special presidential election need occur only if the surviving successor is someone other than the vice president. If the vice president survives the attack (because, for example, she was in the bunker at the time of the attack), she becomes president (not acting president) and nominates a new vice president, confirmed by both houses of Congress. See U.S. ConST. amend. XXV, \&2.

183 The primary benefit of having the vice president or one cabinet member in the secured location at all times is that it prevents this scenario by guaranteeing the safety of one statutory presidential successor at all times.

184 She must, of course, satisfy the constitutional requirements for the presidency-be a natural born citizen of the United States, thirty-five years of age, and fourteen years a resident of the United States. See U.S. Const. art. II, $\$ 1$, cl. 4. The newly-appointed members of the House must take care to ensure that the new Speaker meets those requirements. 
Speaker, who remains as Speaker. Special elections for president and Congress again are held within six months.

\section{CONCLUSION}

It is unlikely that the People are concerned with the constitutional and legal niceties of any continuing government in the wake of a terrorist attack; the public concern is that some federal government continues, through some officials. One would hope, however, that those devising continuity procedures would show greater concern for constitutional detail. It is not enough that there be a continuing federal government. The goal should not be merely the continuity of an executive branch comprised of random remnants.

More consistent succession, continuity, and repopulation plans are possible under the current Constitution and laws, with several adjustments and amendments suggested here. But rulemakers must think in constitutional terms. The goal must be continuity of a federal government that is constitutional and democratically legitimate, because all the political branches exist and all have been filled according to proper procedures. 
